\title{
CHOICE OR COMMONALITY: WELFARE AND SCHOOLING AFTER THE END OF WELFARE AS WE KNEW IT
}

\author{
MARTHA MINOW $\dagger$
}

\begin{abstract}
Reflecting market rhetoric but also potentially advancing spiritual and religious values, school voucher plans dominate current debates on education reform. These voucher plans would enable parents to use public dollars to select private schools, including parochial ones, for their children. Moreover, the recent federal welfare reform includes the "charitable choice" provision, which enables states to issue vouchers to individuals who can redeem them for services and aid from private, including religious, entities. In this Article, Professor Minow predicts that constitutional challenges to these plans under the religion clauses are likely to result in judicial approval of school vouchers and judicial rejection of charitable choice, even though she finds school vouchers the more troubling policy and charitable choice the more promising one. Both kinds of proposals raise challenging questions about individual choice, its reliability, and its importance relative to the need for commonality in society sufficient to bridge plural and potentially divided communities. Yet, both proposals are superior to simplistic al-

$\dagger$ Professor, Harvard Law School. A version of this Article was presented as the Brainerd Currie Lecture, Duke University School of Law, Feb. 18, 1999. I thank Dean Pamela Gann for the invitation and members of the Duke Law School community for engaging questions and comments. Another version of this work will appear in a book entitled Who Provides, which emerged from the Harvard Divinity School Seminar on Democratic Revival. I would like to thank Ron Thiemann and Brent Coffin for involving me in that seminar, seminar participants for their comments, and Edward Baker, Ronald Dworkin, Frank Michelman, Jenny Mansbridge, Thomas Nagel, Rick Weissbourd, and Larry Sager for valuable discussions. Avi Soifer, David Wilkins, David Wang, and especially Larry Blum offered intense scrutiny, for which I am grateful. Thanks especially to Andrew Varcoe for research assistance beyond the call of duty. Thanks to Kate Cook, Catherine Claypoole, Jesse Fisher, Dalia Tsuk, Nina Wang, and Jean Chang for background materials, and to Laurie Corzett for dealing with word processing nightmares.
\end{abstract}


ternatives that assign responsibility for schooling and welfare entirely to homogeneous communities, to the federal government, or to each individual. Voucher proposals, if regulated, can establish constructive partnerships between governments and private, including religious, entities at the local, state, and federal levels.

\section{TABLE OF CONTENTS}

Introduction 494

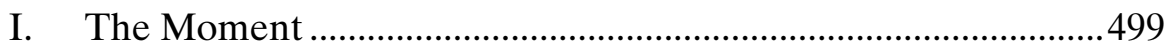

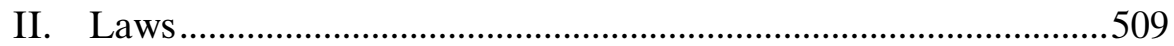

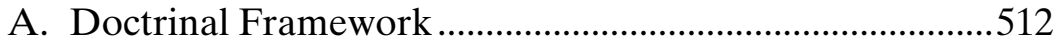

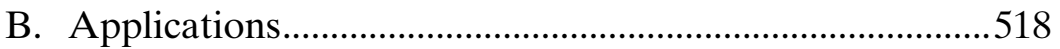

1. School-Choice Programs ...........................................519

2. "Charitable Choice".....................................................528

a. Pervasively sectarian institutions ............................531

b. Government aid to worship and proselytizing ........534

c. Jeopardy to the religious free exercise for the destitute and desperate ....................................536

d. Participation by an identifiable subset of

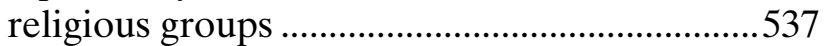

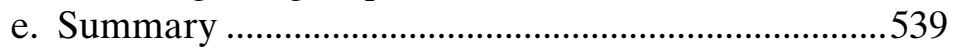

III. The Problems with Simpler Solutions .......................................542

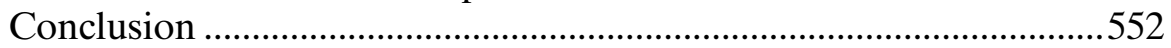

\section{INTRODUCTION}

Private individual choice is a central cultural and legal value in the United States. Often a slogan, it sustains rationales for free-market economic arrangements and constitutional liberties to parent, to exercise religion, and to speak. ${ }^{1}$ Thus, it is probably not surprising

1. On the rise of choice as the vital American focus, see generally LAWRENCE M. Friedman, The Republic of Choice: Law, Authority, and Culture (1990). Many scholars identify how the rhetoric of free choice in varied settings masks sharp constraints on choice. See, e.g., Martha A. Field, Surrogate Motherhood 73, 152 (1988) ("Surrogacy for hire is probably with us for the long term, but society can afford to move slowly in evolving toward the new era of options in childbearing."); MORTON J. HORwITZ, THE TRANSFORMATION OF AMERICAN LAW: THE CRISIS OF LEGAL ORTHODOXY 1870-1960, at 3363 (1992) (discussing the rise of contractual freedom in the 20th century and the systemic changes that have accompanied its growth); Paul Gerwitz, Choice in the Transition: School Desegregation and the Corrective Ideal, 86 COLUM. L. REV. 728, 742 (1986) ("The rhetoric of free choice can mask the fact that the chooser is not allowed to have whatever he wants; in fact, his 
that private individual choice has surfaced as an organizing framework for important reforms of two public systems widely thought to be failing: public schooling and public provision of welfare.

For public schooling, the solution is "school choice," a phrase that encompasses proposals both for vouchers to pay for private schools and for charters to enable new, entrepreneurial public schools. Under each of these plans, parents are permitted to select the schools their children will attend. For public provision of welfare, the solutions already in place in federal law include both time limits for public assistance and "charitable choice." The latter enables states to contract directly with private providers, including religious ones, for the provision of social services, as well as to issue vouchers to individual recipients redeemable for private, often religiously based, assistance. Encircling both solutions is wary skepticism of public institutions and government. ${ }^{2}$ Blamed for inefficiencies and an absence of values, public schools and public welfare need a jolt of competition, or perhaps they should be replaced by private, largely religious providersor so voucher advocates suggest.

Reliance on vouchers for schooling and welfare indeed can promote competition, pluralism, and at least the appearance of private choice. However, such reliance risks diminishing the sense of "we," the collective to which everyone in the country should feel connected or responsible. Vouchers seem to convert public expenditures for public purposes into individualized consumer choices, and this shift

choice of school must be made from a finite 'opportunity set."'); Joan Williams, Gender Wars: Selfless Women in the Republic of Choice, 66 N.Y.U. L. REV. 1559, 1559 (1991) (stating that framing women's rights as a matter of equality requires "a challenge to rhetoric of choice, which deflects attention away from the constraints within which women's choices occur")

2. See generally Why PeOple Don't Trust Government ix (Joseph Nye et al. eds., 1997) (introducing essays discussing "a widespread loss of confidence in and a dissatisfaction with government as it is currently functioning").

3. See John E. Chubb \& Terry M. Moe, Politics, Markets and America's SCHOOLS ix (1990) (proposing "a shift away from a system of schools controlled directly by government - through politics and bureaucracy—to a system of indirect control that relies on markets and parental choice"); John E. Chubb \& Terry M. Moe, America's Public Schools: Choice Is a Panacea, Brookings ReV., Summer 1990, at 5 ("What we propose is a new system of public education that eliminates most political and bureaucratic control through markets and parental choice."); James A. Peyser, School Choice: When, Not If, 35 B.C. L. REV. 619, 619 (1994) (suggesting that choice would "empower" teachers and "engage" parents); see also Martha Minow, Reforming School Reform, 68 FORD. L. REV. 257, 258 (1999) [hereinafter Minow, Reforming School Reform] (noting that voucher advocates "gather under the banner of "choice"). For a thoughtful, critical view of these claims, see James S. Liebman, Book Review, Voice, Not Choice, 101 YALE L.J. 259 (1991) (reviewing CHUBB \& MoE, supra). 
to private providers eliminates or shrinks the common spaces created by public schools and public assistance. Both recipients and providers can retreat from a sense of the collective good to commitments to smaller and perhaps more homogeneous groups, especially if the private providers are affiliated with a particular religious group. Even more troubling is the possibility that people who are neither providers nor recipients can come to see schooling and caring for the poor as outside their sphere of concern. Indeed, they can come not to see these increasingly privatized projects at all.

In a nation as diverse and complex as ours, the tasks of schooling and caring for the poor cannot be managed entirely, or even largely, by private institutions. Private institutions lack sufficient resources. Even if these private institutions are subsidized through public resources, they remain insufficient to promote the public purposes of social cohesion, equal opportunity, and respect for religious and ethnic diversity. Because schooling directly involves preparation of each new generation for adult roles, concern about the large, encompassing good is vital to the establishment of public values in general. But even the provision of welfare deeply implicates core values such as equal respect and individual liberty, not just for welfare recipients but also for the nation as a whole. These public values, embraced by the Constitution, require complex connections between public and private institutions, between general norms and individual freedom, and between secular and religious activities. ${ }^{4}$

4. Powerful and attractive elaborations of such public norms appear in the works of John Rawls. See, e.g., John Rawls, POlitical Liberalism (1993); JoHn Rawls, A THEORY OF Justice (1972); John Rawls, The Domain of the Political and Overlapping Consensus, 64 N.Y.U. L. REV. 233 (1989); see also Christopher L. Eisgruber \& Lawrence G. Sager, The Vulnerability of Conscience: The Constitutional Basis for Protecting Religious Conduct, 61 U. CHI. L. REV. 1245, 1315 (1994) ("To single out one of the ways that persons come to understand what is important in life, and grant those who choose that way a license to disregard legal norms ... is to defeat ... our commitment to toleration."). Valuable efforts to formulate what equal regard could mean appear in Thomas Morawetz, Persons Without History: Liberal Theory and Human Experience, 66 B.U. L. REV. 1013, 1037 (1986) (arguing that the liberal agenda must be defended by "arguing from a completely articulated theory of human interests and experience on which it rests"), and in Laura S. Underkuffler-Freund, Essay, Yoder and the Question of Equality, 25 CAP. U. L. REV. 789 (1996) (discussing the extent to which the concept of equality shapes the understanding of religious decrees). See generally RONALD DWORKIN, LAW's EMPIRE (1986) (theorizing adjudication within a democracy that requires both commitment to overcoming injustice and an acknowledgment of disagreement about the meaning of justice); Thomas NAgel, EQuAlity AND PARTIAlity 99 (1991) (exposing the difference between egalitarianism and commitments to reward people in accordance with their productive contributions); Owen M. Fiss, The Social and Political Foundations of Adjudication, 6 LAw \& HUM. BEHAV. 121 (1982) (considering the sources and the expression of public norms). 
Paradoxically, the turn to vouchers in the current moment reflects both the triumph of the market as the preferred mode for social organization and the resistance to the market mounted especially by people attached to particular religious traditions. After exploring this paradoxical development, I offer both legal and policy analyses of school and welfare vouchers. I suggest that school vouchers are probably constitutional, but troubling in terms of policy; on the other hand, welfare vouchers raise more thorny constitutional problems, but could be good policy.

Whatever the difficulties of the current proposals, they nevertheless hold more promise for meeting the complex demands of constitutionality and good policy than the more simplistic alternatives for social provision. The Article considers three simplistic alternatives that underlie policy debates: leaving each community to care for "its own," assigning responsibility for schooling and welfare support entirely to centralized government, or leaving it instead in the hands of individuals and their immediate families. I show that each of these alternatives is unworkable, undesirable, and potentially unconstitutional. By urging resistance to the temptation to reach for simplicity, I seek to cultivate appreciation for deliberately complex solutions.

Indeed, combinations of individual responsibility and private subcommunity social provisions, joined with coordinating governmental structures, characterize our history ${ }^{5}$ and should guide our future. As a tool for this vision, vouchers can promote pluralism, social cohesion, quality, and equality, and they can help create complex partnerships between private groups and federal and state governments. Vouchers, however, need to be framed more explicitly to advance pluralism and social cohesion, while sustaining and enlarging the settings of public discussions about how this society should meet the needs of poor people and all children. Greater access to improved public and private options and strengthened guarantees can improve school and welfare voucher proposals in both constitutional and policy terms.

By calling for complex solutions, I also mean to describe and defend efforts to enhance both individual freedom and social solidarity. This nation, reflected in its Constitution and laws, embraces complex and multiple social values: freedom and communality, equality and religious variety, individual and communal responsibility. These mul-

5. See infra notes $37-45$ and accompanying text; infra Part III. For a rich exploration of the roots of American pluralism, see generally Michael KAMMEN, PEOPLE OF PARADOX: AN INQUIRY CONCERNING THE ORIGINS OF AMERICAN CIVILIZATION (1972). 
tiple values are not simply distinct and competing; they are also linked and interdependent. As manifested in our legal system, individual freedom relies on a collective structure of rules and institutions. Religious pluralism relies on overarching laws mandating tolerance but also setting limits on the government's involvement and support. At work in these arrangements are nuanced understandings of the interdependence of individuals, of individuals and groups, and of people and governing structures. No one can make it through life all alone, and no group ever sustains itself without the support and respect of the larger polity. We need plural communities, institutions, and structures; we also need the larger public framework devoted to that plurality and to individuals who may, but also who may not, be comfortably situated within a caring community. ${ }^{6}$ How we respond to

6. Emerging at the turn of the century, pluralism as an American philosophy insisted on the plurality and distinction of things and the impossibility of a single law or frame for encompassing all domains of being, even while exploring forms of unity. See JEAN WAHL, THE Pluralist Philosophies OF ENGLAND AND AMERICA 317-18 (1925) (listing in chronological order various definitions of pluralism). Especially as developed by William James, pluralism offered a theory of knowledge that stressed the multiplicity of knowers and forms of knowledge. See William James, A Pluralistic Universe 321-22 (1909) ("[T]he pluralistic view which I prefer to adopt is willing to believe that there may ultimately never be an all-form at all, that the substance of reality may never get totally collected, that some of it may remain outside of the largest combination of it ever made...."); see also NELSON GOODMAN \& CAtherine Z. Elgin, Reconceptions in Philosophy and Other ARTS ANd SCIENCes 24 (1988) ("A number of independently acceptable systems can be constructed, none of which has a claim to epistemological primacy."); Hilary Putnam, Pragmatism: An Open Question 30-31 (1995) (describing Kant's tendency toward pluralism, particularly in the various interactions between the scientific image of the world and the moral image of the world). Horace Kallen described cultural pluralism as the preservation of each ethnic group rather than a melting pot in which each group loses its distinctiveness. See HORACE M. KALLEN, Democracy Versus the Melting-Pot, in Culture and Democracy IN THE United States 67, 125 (1924). Harold Laski suggested that in a pluralist view of culture and politics, the state is only one association to which a person belongs. See HAROLd J. LASKI, The Sovereignty of the State, in STUdies IN THE PROBlem OF SOVEREIGNTY 1, 19 (1917) (stating that one must regard the state as only one association to which one belongs "and give it exactly that pre-eminence and no more").

More recent theories of interest group pluralism emphasize the importance of groups organized around particular interests in political activities, but they retain individual autonomy as a central principle; communitarians and republicans, on the other hand, search for a way to connect group life and individual fulfillment. See, e.g., Gregory S. Alexander, Dilemmas of Group Autonomy: Residential Associations and Community, 75 CoRnell L. ReV. 1, 2-3 (1989) ("Pluralists and public-choice theorists believe that individuals associate with each other only to achieve specific ends coincidentally shared.... But ... communitarian theory understands group activity and individuality as simultaneously present ...."); Richard H. Fallon, What is Republicanism, and Is It Worth Reviving?, 102 HARV. L. REV. 1695, 1697 (1989) (describing republicanism as boiling down to the core tenet that human beings are essentially political animals). Moral pluralism, another connected theory, holds that there is not a single good for 
seemingly appealing ideas today will affect how we fulfill these complex needs in the future.

\section{THE MOMENT}

Across the globe, we are witnessing a tidal change in the role of governments in providing for basic human needs. Western democracies are backing away from the social welfare state created through democratic politics. In the name of producing stable currencies and of securing promising positions in the global economic markets, Canada and countries across Europe are cutting back on social welfare guarantees. ${ }^{7}$ Here in the United States, devolution of governmental responsibility to the states constitutes part of a larger withdrawal of the federal commitment to providing economic relief for the poor, as originally established by the New Deal. ${ }^{8}$ Even formerly socialist countries like Russia are cutting back on basic social guarantees ranging from child care to police protection. ${ }^{9}$

every individual nor a common measure for evaluating all that is good, but it does not abandon an ethical commitment to identifying objectively bad and objectively good conditions and actions. See William A. Galston, The Legal and Political Implications of Moral Pluralism, 57 MD. L. ReV. 236, 241 (1998). But see John KeKes, The Morality of Pluralism 204-06 (1993) (criticizing the theory of moral pluralism).

A leading exponent of this kind of pluralism is Robert Cover. See Narrative, VIOLENCE, AND THE LAW: THE EsSAYS OF ROBERT COVER passim (Martha Minow et al. eds., 1992) (developing a conception of pluralist communities within which human norms are generated); see also Sylvia R. Lazos Vargas, Democracy and Inclusion: Reconceptualizing the Role of the Judge in a Pluralist Polity, 58 MD. L. REV. 150, 154 (1999) (arguing that the Supreme Court should recognize the multitude of views and perspectives that exist in American society). One defect of pluralist ideas when applied to social organization tends to be neglect of individuals who are not associated with any particular group or who are subject to maltreatment simply because of their apparent group membership. I mean to address precisely these issues, while acknowledging the power and attractions of pluralist traditions.

7. See Nicolas Spulber, Redefining the State: Privatization and Welfare REFORM IN INDUSTRIAL AND TRANSITIONAL ECONOMICS 73-104 (1997) (discussing the revival of rhetoric about the state's "excessive" and "inappropriate" expansion in the West); Jonathan B. Cleveland, School Choice: American Elementary and Secondary Education Enter the 'Adapt or Die' Environment of a Competitive Marketplace, 29 J. MARSHALl L. REV. 75, 78 (1995); Helene Cooper, All of Europe Watches as Britain's Tony Blair Hacks Away at Welfare, WALL ST. J., June 25, 1998, at A18.

8. See infra Part II.B.2 (discussing welfare reform).

9. In Russia, for example, many individuals now arrange for their own police protection. See Fred Hiatt, Cities of Violence; Moscow; Police Force 'Choking on a Flood of Crime', WASH. PosT, Nov. 7, 1993, at A41 ("'If the state is unable to provide justice, economic subjects start to solve problems in other ways, using crime, guns, mafias, and private guards."' (quoting Arkady Murashov, a politician and former Moscow police chief)). 
Taking the place of social welfare guarantees are policies intended to harness the competitive efficiencies of the free market and to promote individual consumer choice. ${ }^{10}$ The rhetoric of competition and choice permeates reform proposals for numerous programs such as Social Security, where individual retirement accounts are the rage. ${ }^{11}$ Choice rhetoric also dominates the traditionally public sphere of children's schooling. ${ }^{12}$ The new ideal, at least as captured in slogans, seems to be maximal individual choice for students and parents regarding both the type of school attended and its location. ${ }^{13}$ School-

10. The vivid phrase "creative destruction" has been used to capture both the growth and movement that markets promote. See JOSEPH A. SCHUMPETER, CAPITALISM, SOCIALISM AND DEMOCRACY 81-86 (1947) (describing capitalism as a method of economic change that opens markets, generates new products and organizations, and bombards and destroys existing firms at their foundations).

11. See Social Security and the Market, N.Y. TIMES, Jan. 22, 1999, at A24 (describing proposals for individual retirement accounts to supplant Social Security in part or in full); see also Clifford Krauss, Social Security, Chilean Style, N.Y. TIMES, Aug. 16, 1998, §4, at 4 (describing the United States' interest in Chilean privately managed, individually owned retirement accounts).

12. Milton Friedman argued for market approaches to schooling as early as 1962. See generally Milton Friedman, CAPITALISM AND FREEDOM (1962). By 1998, the argument had become mainstream. See Cleveland, supra note 7, at 80 (commenting that without the possibility of consumer choice, schools have fewer incentives to "provide a quality product to captive customers"); Steven K. Green, The Legal Argument Against Private School Choice, 62 U. CIN. L. REV. 37, 37 (1993) (acknowledging that school choice has become the focus of the 1990s educational debate); Adam Cohen, A First Report Card on Vouchers (April 19, 1999) $<$ http://cnn.com/ALLPOLITICS/time/1999/04/19/vouchers.html> (on file with Duke Law Jour$n a l)$. Although choice options may dominate the rhetoric of school reform, they have not yet prevailed in practice[,?] as evidenced by the small percentage of students actually involved in charter schools and voucher programs. See Matthew Miller, A Bold Experiment to Fix City Schools, AtLANTIC MonTHLY, July 1999, at 15, 16 (advocating an expansion of voucher programs). Miller observes:

Just over 52 million students attend grades K through 12 in the United States. Only two cities offer publicly funded vouchers: in Milwaukee (whose breakthrough program was begun in 1990) roughly 6,000 of 107,000 students get vouchers; in Cleveland about 4,000 of 77,000 do. In May, Florida approved a plan under which students at the poorest-performing schools would get vouchers. Four schools are expected to be eligible this year, and 12,000 of the state's 2.3 million K-12 kids are expected to use vouchers over the next four years. Privately funded voucher programs in thirtyone cities served roughly 12,000 children last year; ten new such programs came into being for the 1998-1999 school year....

Add these number up and you get 74,000 children-about 0.1 percent of students. Add 200,000 for those students in the 1,200 charter schools around the country (which also give parents a choice), and the proportion comes to only 0.5 percent of schoolchildren.

Id.

13. See, e.g., Children's Educational Opportunity Foundation, The School Choice Debate (visited Sept. 22, 1999) <http://www.childrenfirstamerica.org/debate.html> (proclaiming "Take away their choice-Take away their chance") (on file with the Duke Law Journal); see also 
ing is increasingly viewed as a private consumption item, instead of a shared experience for children from all classes, races, and ethnic backgrounds. Within the public school system, magnet and charter schools offer students options beyond the neighborhood school. ${ }^{14}$ Public school systems experiment with parental choice of particular school buildings and programs for their children. ${ }^{15}$ Public tax credits and vouchers stretch this expanding arena of choice even farther, so that even students whose families lack sufficient resources to opt out of the public system can do so. ${ }^{16}$ Fifteen states and the District of Columbia are considering additional programs to expand the school choices of low-income parents, or all parents, through vouchers, tax relief, or other mechanisms. ${ }^{17}$ The multitude of state legislative proposals for vouchers, scholarships, and tax credits to enable the selection of private schools indicates a genuine possibility of major revision in how society wishes to educate its children. ${ }^{18}$

JefFrey R. Henig, Rethinking SChOOl Choice: Limits OF THE MARKet MetaPHOR 78-96 (1994) (describing school-choice initiatives as market ideology rather than a concrete policy initiative); Dan Morrison, The Rudys Stand Fast: Two Remain at Odds over Voucher Plan, NEWSDAY, Mar. 7, 1999, at A4 (describing a lobbying organization called Change-NY, which ultimately seeks a voucher system giving individual families public dollars and the ability to select private or parochial schools of their choice).

14. See Cleveland, supra note 7, at 96-98 (describing choice models); see also Phillip T.K. Daniel, A Comprehensive Analysis of Educational Choice: Can the Polemic of Legal Problems Be Overcome?, 43 DePAul L. REV. 1, 11, 17 (1993) (describing magnet and charter schools as public schools with specialized programs and enrollments open to students from across the district); Peyser, supra note 3, at 619-32 (describing school-choice models); Justine J. Sayie, Education Emancipation for Inner City Students: A New Legal Paradigm for Achieving Equality of Educational Opportunity, 48 U. MIAMI L. REV. 913, 940 (1994) (arguing that providing vouchers would sever the link between "residential location and school quality"); Priscilla Wohlstetter, Education by Charter, in SchoOl-BASED MANAGEMENT: ORGANIZING FOR HigH Performance 139 (Susan Albers Morhman \& Priscilla Wohlstetter eds., 1994) (describing a charter school idea).

15. See Peyser, supra note 3, at 621 (discussing intradistrict public school choice).

16. See id. (discussing private choice based on state-funded vouchers); see also Quentin L. Quade, A Primer on Educational Choice (visited Sept. 22, 1999) $<\mathrm{http} / /$ www.marquette.edu/blum/primer.html > (on file with the Duke Law Journal). On the vexed subject of whether tax credits and exemptions should be viewed in the same way as vouchers or subsidies, see Edward A. Zelinsky, Are Tax "Benefits" Constitutionally Equivalent to Direct Expenditures, 112 HARV. L. REV. 379 (1998).

17. See Nina Shokraii Rees \& Sarah E. Youssef, School Choice 1999: What's Happening in the States (visited Sept. 6,1999) <http://www.heritage.org/schools> (on file with the Duke Law Journal) (providing a state-by-state summary of proposed and enacted voucher programs). Thus far, federal legislation on the subject has been introduced and rejected several times. See $i d$. (noting that President Clinton vetoed two school-choice bills in 1998).

18. Dramatic reshaping of American education will not happen without contest. Several lawsuits challenging such state plans recently reached judicial decisions. The Vermont Supreme Court recently found that the Chittenden School District's plan to permit parents to use public 
These market-based proposals seem to offer ways to cut through public bureaucracies. School choice seems the answer for parents and children who feel that they have had no control over what happens in public schools. As education becomes ever more central to economic opportunity and job security, increasing parental choice may provide an important means of managing some kinds of anxieties about children's futures and frustration with sclerotic state and local bureaucracies. Advocates argue that by promoting competition and consumer sovereignty, school choice would force drastically needed changes and increase efficiency, even at the price of some failures. ${ }^{19}$

In addition, these proposals reflect growing disillusionment with public schools and the increasing reliance on private and religiously affiliated schools to foster the moral, disciplinary, or group identity aspects of their children's education. ${ }^{20}$ Although seldom discussed,

dollars to send their children to religious schools violated the Vermont Constitution. See Chittenden Town Sch. Dist. v. Vermont Dep't of Educ., No. 97-275, 1999 WL 378244, at *37 (Vt. June 11, 1999). In contrast, the Maine Supreme Court held that a state voucher plan that excluded religious schools did not violate the federal Constitution, see Bagley v. Raymond Sch. Dep't, 728 A.2d 127, 135, 147 (Me. 1999) (rejecting free exercise, establishment, and equal protection challenges), and the First Circuit similarly found no constitutional problems with Maine's voucher plan, see Strout v. Albanese, 178 F.3d 57 (1st Cir. 1999) (rejecting the same challenges). The Ohio Supreme Court recently rejected First Amendment challenges to a Cleveland voucher plan that included religious schools. See Simmons-Harris v. Goff, 711 N.E.2d 203, 208-12 (Ohio 1999). In Wisconsin, the supreme court found that a Milwaukee choice plan allowing students to attend both sectarian and nonsectarian private schools at taxpayer expense did not violate the state constitution. See Jackson v. Benson, 578 N.W.2d 602, 613-22 (Wis. 1998), cert. denied, 119 S.Ct. 466 (1998).

Although the United States Supreme Court declined to review the Wisconsin decision, Court observers suggest that the emerging conflicts among judicial responses will require Supreme Court review before long. See Court Backs Maine Law on School Vouchers, Those Who Feel the State Should Pay Student Tuition at Religious Schools Vow to Appeal Further, PORTLAND PRESS HERALD, June 2, 1999, at 1A (describing the efforts of voucher proponents to have a voucher case heard by the Supreme Court). Voucher proposals have also been considered in Florida, Pennsylvania, Texas, and Minnesota, among other states. See Terrence Stutz, Legislative Leaders Focus on Education, Dallas Morning News, June 1, 1999, at 3A. Controversy over vouchers has divided political and community leaders across the country. See, e.g., Dan Barry, Crew Threatening to Resign His Post as Schools Chief, N.Y. TIMES, Mar. 4, 1999, at A1 (detailing conflicts over vouchers between Mayor Rudolph Giuliani and school chancellor Rudy Crew); Council of Great City Schools, Resolution: Private School Vouchers (Mar. 24, 1996) <http://www.cgcs.org/services/onissues/resol8.htm> (on file with the Duke Law Journal) (providing the text of a school council anti-voucher resolution issued in response to proposals in Congress and in state legislatures).

19. See Note, The Limits of Choice: School Choice Reform and State Constitutional Guarantees of Educational Quality, 109 HARV. L. REV. 2002, 2002 (1996) [hereinafter The Limits of Choice] (suggesting that a true free market for education will pose an inherent risk of creating failures as well as successes).

20. Although these are expansive claims about the academic successes of private, and es- 
the disillusionment with public schools began at just about the same time that these schools took on the task of educating all children, including those with disabilities and limited English proficiency, noncitizens, the homeless, and migrants. ${ }^{21}$ The rush of leaders toward choice proposals both in and beyond public schools may in no small way respond to the ambitious and troubled diversity in public school enrollments. $^{22}$

However, the movement for school choice also finds support from those critical of market values and a secular, competitive world. ${ }^{23}$ Religious leaders and other individuals blame public schools for inculcating in children a culture of self-interest bereft of any obligations to society. ${ }^{24}$ For some, religious values taught in religious schools can challenge the commercialization of everyday life, including the targeting of children as consumers. ${ }^{25}$ School vouchers thus

pecially religious, schools, see, e.g., CHUBB \& MOE, supra note 3; JAMES S. COLEMAN ET AL., High SCHOOL ACHIEVEMENT (1982), it is impossible thus far to separate their apparent successes in retaining enrollments and boosting academic performance from the self-selection of families and the private schools' abilities to refuse and to expel troublesome students, see Arthur S. Goldberger \& Glen G. Cain, The Causal Analysis of Cognitive Outcomes in the Coleman Hoffer and Kilgore Report, 55 Soc. OF EDUC. 103-22 (1982); J. Douglas Willms, CatholicSchool Effects on Academic Achievement: New Evidence from the High School and Beyond Follow-up Study, 58 Soc. OF EDUC. 98-114 (1985).

21. See Minow, Reforming School Reform, supra note 3, at 277-80 (discussing how public schools have moved to include students with disabilities and limited English proficiency).

22. Sources of educational reform agendas are complex. See Chris Pipho, Eagle Eyes and Rabbit Ears: Locating Policy Issues, 80 PHI DELTA KAPPAN 645, 645-46 (1999).

23. See Perry Glanzer, Religion in Public Schools, 80 PHI Delta KAPPAN 219, 219-20 (1998) (noting that vouchers would help parents who are concerned that the secular values taught in schools might steer children away from religion); Michael McConnell, Multiculturalism, Majoritarianism, and Educational Choice: What Does Our Constitutional Tradition Say?, 1991 U. CHI. LEGAL. F. 123, 125-127 (1991) [hereinafter McConnell, Multiculturalism, Majoritarianism, and Educational Choice] (arguing that school choice would promote a desirable form of multiculturalism); Ruti Teitel, Vouchsafing Democracy: On the Confluence of Governmental Duty, Constitutional Right, and Religious Mission, 13 Notre DAME J.L. ETHICS \& PUB. POL'Y 409, 417-18 (1999) (noting that because most private schools are religiously based, vouchers would effectively shift responsibility for education from the government to churches).

24. See Robert S. Alley, Public Education and the Public Good, 4 WM. \& MARY BILl of RTS. J. 277, 348 (1995) (arguing that public schools are already balkanized by interest group pressures and that vouchers will only exacerbate the problem); McConnell, Multiculturalism, Majoritarianism, and Educational Choice, supra note 23, at 150 (suggesting that the current public school system, by valuing all perspectives equally, fails to impart any value beyond selfinterest and "teaches our children, unintentionally, to be value-less, culture-less, root-less, and religion-less").

25. Spokespersons associated with both the right and left wings in American politics urge efforts to strengthen civil society-the institutions, associations, and practices that occupy realms between individuals and the state. See Adam B. Seligman, The IdeA OF CiviL SOCIETY passim (1992) (discussing the history and relevance of the idea of civil society). A re- 
may offer a way to rechannel taxpayer dollars to schools that instill values and discipline. Similarly, many people criticize secular social services for failing to provide a moral framework in which to encourage more responsible behavior. The public welfare system, it is said, fails to forge social connections between those who are isolated and despised and those who are relatively comfortable and privileged. ${ }^{26}$ Moreover, public welfare is faulted for not respecting the individuality or personhood of people in need. ${ }^{27}$ To some, religious charities are more successful at inculcating values and discipline in the poor. Welfare vouchers thus provide a way to turn care of the poor over to such religious charities.

Academics and pundits, too, argue that a vital democracy depends on individuals' engaging in mutual aid and recreation apart from the market or the polity. Robert Putnam's work is among the most renowned. ${ }^{28}$ His research indicates that self-government and

lated project is the promotion of a communitarian agenda, which has support from both the right and left wings of the American political spectrum. See, e.g., AMITAI ETZIONI, THE SPIRIT of COMmunity: Rights, Responsibilities AND THE COMMUNITARIAN AgENDA passim (1993) (advocating increased emphasis on community as an alternative to big government); William Sullivan, Reconstructing Public Philosophy 208-27 (1986) (calling for America to foster civil society and civic involvement by strengthening communities and emphasizing the need for interdependence among people). This sort of advice is often directed to emerging democracies, such as those in Eastern Europe, and is suggested as a means by which such countries could reduce government involvement in economics and social life. However, the advice is no less applicable to free-market, industrialized societies, in which civic participation has declined drastically. Thus, the market idea is interdependent with the existence of thriving, private cultures, such as religious communities, that can cultivate the qualities of trust, hard work, and emotional support that markets paradoxically require or jeopardize.

26. There is a notable distinction, however, between opposition to public welfare per se and opposition to secular provision of public dollars for dependents, since those same dollars could be channeled through private religious groups. Some religiously motivated arguments are antimarket (although others are friendly to capitalism); some are antigovernment; some oppose the teaching of secular and egalitarian values; some oppose what they regard as the amorality communicated by public institutions such as schools and welfare agencies. On the varieties of conservatism in the United States, see generally RALPH E. ELLSWORTH \& SARAH M. HARRIS, The American Right Wing (1962); Gillian Peele, Revival and Reaction: The Right In CONTEMPorary America (1984); Alan Wolfe, The Revolution That Never Was, New REPUBLIC, June 7, 1999, at 34 (reviewing books on conservatism).

27. See, e.g., MARVIn N. Olasky, THE TRAgEdy OF AMERICAN COMPASSION 233 (1992) (commenting that governmental welfare programs are deficient in "treating people as people").

28. See Robert D. Putnam, Bowling Alone: America's Declining Social Capital, 6 J. DEMOCRACY 65, 66 (1995) [hereinafter Putnam, Bowling Alone] (arguing that American civil society is in decline because fewer Americans participate in social institutions and informal community activities, such as bowling); Robert D. Putnam, Tuning in, Tuning out: The Strange Disappearance of Social Capital in America, 28 PS: POL. SCI. \& POL. 664, 664-83 (1995) (dis- 
civic participation are closely tied to degrees of communal connection and involvement. ${ }^{29}$ Without the kinds of ties forged by bowling leagues, volunteer groups, mutual aid societies, and religious organizations, civic engagement suffers. ${ }^{30}$ Indeed, both Republican and Democratic leaders urge efforts to strengthen civil society, especially the use of nonprofit organizations and community groups to meet the needs of vulnerable and at-risk groups. ${ }^{31}$

Nevertheless, this call for more is often coupled with policies of less. Congress recently ended the federal welfare entitlement. ${ }^{32}$ Local communities have widely rejected school levies and criticized the costliness of public education expenses, such as special education for students with disabilities. ${ }^{33}$ Contemporary public debate thus reflects a complex mixture of confidence in market competition and efficiency, individual choice, pluralism, and private religious institutions,

cussing possible reasons why Americans appear to be participating less in civil society). For critiques of Putnam's work, see Michael Schudson, The Good Citizen: A History of AMERICAN LIFE 296-98 (1998) (analyzing possible shortcomings in Putnam's data and suggesting that "even if Putnam's data holds up, it would still be premature to infer from it a decline in civic participation"); Richard L. Hasen, Voting Without Law?, 144 U. PA. L. REV. 2135, 2154 n.8 (1996) (detailing several criticisms of Putnam's work); Katha Pollitt, For Whom the Ball Rolls, NATION, Apr. 15, 1996, at 9 (offering a critique of Putnam's Bowling Alone).

29. See Putnam, Bowling Alone, supra note 28, at 66-67.

30. See id. at 67.

31. Former U.S. Senator Bill Bradley, a Democrat, and former Mayor of Indianapolis Stephen Goldsmith, a Republican, are two politicians committed to strengthening civil society. See Conversation with Thomas Sander, Program Director, Saguaro Seminar, John F. Kennedy School of Government, Harvard University (Sept. 1, 1999). Bradley is currently running against Vice President Gore to be the Democratic party's nominee for President, see Adam Clymer, $A$ Surprise Possibility: A Dignified Democrat Race, N.Y. TIMES, Oct. 28, 1999, at A28, while Goldsmith is now a policy advisor for Republican presidential contender Governor George W. Bush and continues to advocate collaborations between government and religious organizations, see Dana Milbank, What W. Stands for: Wishy-Washy or Wise?, New REPUBLIC, Apr. 26, 1999, at 66 (discussing Goldsmith's political positions).

32. For example, the Personal Responsibility and Work Opportunity Reconciliation Act of 1996, commonly known as the Welfare Reform Act, markedly cut back the federal government's involvement in providing social services to the needy. See Personal Responsibility and Work Opportunity Reconciliation Act of 1996, Pub. L. No. 104-193, 110 Stat. 2105 (codified in scattered sections of 42 U.S.C.).

33. The difficulty of passing tax levies to support public schools has been widely noted. See, e.g., Ann Fisher et al., State-Aid Pledge Swayed Voters, Columbus Dispatch, Nov. 5, 1998, at 1A (describing a successful school bond issue that followed a string of rejected school levies dating back to 1968); Robert Starr, Legislative Race Set by Primary, Boston Globe, May 9, 1999, at 5 (describing repeated failures to authorize tax overrides in towns seeking funding for public schools). On concerns about costs of special education, see Norman Draper, Minneapolis School Budget Balanced; Board's Intended Cuts Much Less Painful Than Expected, MinNEAPOLIS STAR TRIB., June 23, 1999, at 3B. 
and of distrust or disdain for collective social provision. The political tilt of the voucher debates is therefore complex. School-choice policies, for example, seem to appeal to both suburban middle-class parents and inner-city working-class parents, who each seek more control over the very different educational options available to their children. ${ }^{34}$ Voucher programs are the perfect meeting ground for both market believers and market critics.

Vouchers, however, should prompt several questions: Would vouchers enabling individuals to purchase private, religious schooling and social welfare services harmfully blur the boundaries between the public and private spheres? Would they offer more people exits from common life into private sectors divided by religion, race, and/or class? Would increasing activity by religious groups in schooling children and in providing food, shelter, childcare, job-training, counseling, and treatment so alter the nation's fabric as to shrink what is public or to alienate those who differ from the religious affiliations of growing schools and service providers?

The first response to such questions must be that the blurring of public and private, secular and religious, already exists throughout the United States. Private organizations, particularly those that are religiously affiliated, already play major roles in the provision of schooling, food, shelter, and social welfare services, as well as health care. ${ }^{35}$ Often such private organizations work closely with the state through contracts, reimbursement from public third-party payers, other material assistance, and referrals. ${ }^{36}$ Consider, for example, the

34. See, e.g., Cal Thomas, Opponents Speak for Themselves, Not the Poor: Learning to Love School Choice, Cincinnati EnQuirer, May 6, 1999, at A16 (citing a Phi Delta Kappa Gallup Poll indicating that $56 \%$ of parents with children in public schools support school choice, with higher percentages in some minority and low-income communities). Note that the largest school-choice policy-the districting system that allows affluent families to move to exclusive suburbs and to deduct high property taxes from taxable incomes-excludes those without sufficient resources. See Prepared Testimony of Joe Nathan Ph.D. and Director Center for School Change, University of Minnesota Humphrey Institute of Public Affairs Before House Education and the Workforce Committee, FeD. News ServiCE, May 25, 1999.

35. See Lawrence Cremin, American Education: The Metropolitan Experience 1876-1980, at 273-321 (1988) (describing the role of public and private social service institutions in providing and supporting education); see also Catholic Charities USA(visited Aug. 31, 1999) $<$ http://www.catholiccharitiesusa.org > (on file with the Duke Law Journal) (describing the activities of a Catholic charitable organization); United Methodist Church Official Site: Faith in Action (visited Aug. 31, 1999), <http://www.umc.org/faithinaction> (on file with the Duke Law Journal) (describing the activities of a Methodist charitable organization).

36. See Comments of Father Brian Hehir, Harvard Divinity School Seminar on Democratic Revival (Mar. 9, 1998); see also Ernest Tucker, More Parishes Running in the Red, CHI. 
roles played by Catholic Charities USA, and Catholic schools, particularly in urban areas across the country. Local parishes have provided schools and assistance to the poor with no public support (beyond tax exemption) since colonial times. ${ }^{37}$ Changing demographic patterns and the policies launched by the second Vatican Council in 1962 promoted a deliberate shift in church-run services and schools. ${ }^{38}$ Rather than focus exclusively on serving Catholics, the services and schools now support diverse populations in need and work to advance a human society by modeling human cooperation for the common good. ${ }^{39}$ Of course, these church-run activities may also be seeking converts. For many working-class people, including many nonCatholics, Catholic schools afford avenues for educational advancement, moral development, and order in the midst of urban decay. ${ }^{40}$ Furthermore, public school systems implicitly depend on the existence of Catholic schools to provide slots for children otherwise eligible for public schooling, depending upon the particular surges and declines in school-aged enrollments. ${ }^{41}$

In the contexts of child protective services, foster care, and health care, the functional and financial ties between religiously based programs and public commitments are even stronger. ${ }^{42}$ Catholic agencies receive contracts from municipalities to provide child protective services and foster care, job training and drug counseling, and food pantries and homeless shelters. ${ }^{43}$ Catholic hospitals serve Medicare

Sun-TiMES, Jan. 22, 1999, at 40 (noting that the Chicago city government provided emergency financial assistance to private Catholic schools in the Chicago area).

37. See Anthony S. Bryk et Al., Catholic Schools And the Common Good 17-18

(1993) (describing the early history of Catholic schools in America).

38. See id. at $46-51$.

39. See id. at 10, 51-54.

40. See id. at 52-54; Lona O'Connor, In Vouchers, Archdiocese Sees Way to Save InnerCity Schools, Sun-Sentinel (Ft. Lauderdale), Mar. 21, 1999, at 4B (discussing the role of Catholic schools in providing quality opportunities for poor children, and the potential role of private donations in expanding the number of students who can enroll in Catholic schools).

41. See Rodney J. Thoulion, Editorial, Let's Work Together to Improve Education, NEW ORLEans Times-PiCAYune, May 8, 1999, at B6 ("If our Catholic schools ceased to exist, student transfers to public schools would bankrupt the state. Nonpublic school students number 125,000 statewide, which saves taxpayers over $\$ 370$ million.”); Tucker, supra note 36 , at 40 (noting that Catholic schools enroll over 131,000 students in the Chicago area).

42. See Conversation with Professor Elizabeth Bartholet, Harvard Law School (Sept. 2, 1999); see also Eileen Swift, "Mr. Tom”: He's a Real Class Act, NewsDAY, Oct. 1, 1995, at A70 (documenting how a Catholic agency places children in foster care and houses children on its campus).

43. See, e.g., Steve Chapman, A Judge's Tunnel Vision on School Vouchers, CHI. TRIB., Aug. 29, 1999, at C21 ("Government funds cover no less than 74 percent of the budget for 
and Medicaid patients, Catholics as well as non-Catholics. ${ }^{44}$ Heads of public departments and agencies regularly rely on programs created and run by Catholic agencies (as well as programs created and run by other religious groups) in order to provide responses to human needs as authorized by their public mandates.

Instead of trying to place walls of separation between public and private, and between church and state, only to breach or ignore them again and again, it would be more appropriate to determine how to allocate responsibilities in a world that mixes public and private. ${ }^{46} \mathrm{In}$ deed, we should think about ways to promote partnerships between public and private in order to enhance the actual delivery of services, to respect human individuality and group affiliations, and to enlarge intellectual and moral resources for dealing with the potentially destructive features of global markets. That said, the allocation question should not obscure the larger issue of responsibility. What matters is not just who delivers schooling or aid to the destitute, but who is responsible for seeing that it is actually provided. Religious groups enact one vision of responsibility, but they do not and cannot substitute for a broader umbrella covering multiple religious groups, as well as

Catholic Charities of Chicago."); Torry Minton, S.F. Archbishop Agrees to Discuss Partners Policy, S.F. Chron., Feb. 7, 1997, at A21 ("About 40 percent of the Catholic Charities budget [in San Francisco] flows through City Hall.”).

44. The widespread reliance of communities on Catholic hospitals as chief health care providers willing to serve Medicaid patients can pose problems since patients may want birth control that the Catholic institutions will not provide. See Jayne O'Donnell, Antitrust Health Fight: Catholic Hospital Deals Limit Access, USA TODAY, Apr. 8, 1999, at 1B (noting how lowincome Medicaid recipients lose access to birth control because the only available hospitals are Catholic hospitals that do not provide those services).

45. Catholic Charities of Chicago, for example, receives $74 \%$ of its budget from public money; for Catholic Charities of San Francisco, the figure is closer to $40 \%$. See Chapman, supra note 43; Minton, supra note 43. Religious charities often perform public contracts in the fields of child protection, foster care, adolescent counseling, and substance abuse counseling. As public welfare programs have diminished, pressure on religious charities to meet the needs of those who used to be able to turn to governmental programs has increased. See, e.g., LISBETH B. Schorr, Common Purpose: Strengthening Families and Neighborhoods to REBUILD AMERICA 93-94 (1997) (describing how reductions in government services have increased the demands on charitable organizations); Sandi Dolbee, Preacher to Unite Ministries by Donning Government Role, SAN DIEGO UnION-TRIB., Sept. 11, 1998, at E1 (describing a minister who was hired by a county government to help catalog religious charities and to improve public access to them as part of a county campaign to reduce government welfare expenditures). New developments, such as the charitable choice provision depart from past practices by permitting public contacts with churches themselves, rather than with the nonprofit arms of the religious organizations. See infra notes 130-35 and accompanying text.

46. See infra Part II.A (rejecting doctrinal formulation of religious clauses in terms of a wall of separation). 
people neither choosing nor chosen by religious communities. On a more practical note, the financial bankruptcies of so many Catholic schools and agencies give some clue as to why they cannot accept ultimate public responsibility for providing schooling and social welfare. ${ }^{47}$ Religious leaders have been among the most outspoken in objecting to the prospect of turning social provision entirely over to private charity. ${ }^{48}$ Some form of shared responsibility, connecting governments with private groups (both religious and nonreligious) seems both most practical and most fitting.

Yet, no practical and coherent conception of social provision can proceed without facing the constraints imposed by the United States Constitution and its interpretation by the courts. I thus examine the legal constraints on methods of social provision, paying particular attention to the protection of religious liberty and the prohibition against state establishment of religion.

\section{LAWS}

The First Amendment to the United States Constitution sets limits on social provision arrangements involving the government. Specifically, the First Amendment prohibits the federal government and the states from conducting themselves in a way that amounts to either a governmental establishment of religion or a burden on individuals' free exercise of religion. ${ }^{49}$ Mentioned first in the Bill of Rights, the religion clauses may overlap with but also remain distinct from other

47. See Nina J. Easton, The Year of 2016 and American Society Has Finally Become Civilized, L.A. TIMES, May 19, 1996, at 22 (noting how Catholic Charities nearly faced bankruptcy in 1995); Alva James-Johnson, Social Service Agencies Facing a Refocusing, OMAHA WORLDHERALD, Oct. 18, 1995, at 15SF (describing how Catholic Charities was closing residential facilities because of costs); Steve Kloehn, Cash-Strapped Archdiocese Drops Charter-School Ideas, CHI. TRIB., Sept. 2, 1999, at 1 (discussing how the archdiocese abandoned ideas for charter schools because the Catholic school system was financially strapped); Tim O'Neil, Archdiocese Seeks to Lower Debt, ST. LOUIS Post-DisPatch, Oct. 20, 1995, at 12A (describing a Catholic archdiocese that had been running budget deficits for nine years); Ernest Tucker, George Shapes His Inside Circle, CHI. Sun-TIMES, May 2, 1999, at 24 (describing various problems in a large Chicago archdiocese, including financial problems with church-run Catholic schools).

48. See infra notes $165-70$ and accompanying text.

49. The text of the First Amendment states, in part: "Congress shall make no law respecting an establishment of religion, or prohibiting the free exercise thereof...." U.S. CONST. amend. I, cl. 1. The Supreme Court applied the First Amendment's Establishment Clause to the states in 1963. See School Dist. of Abington Township v. Schempp, 374 U.S. 203, 215 (1963) 
rights, including the freedoms of speech and assembly and the guarantees of due process of law.

Today's Supreme Court, however, must interpret the First Amendment in a world quite different from the one known by the Framers. As Justice William J. Brennan noted in 1963,

[The] religious composition [of the United States] makes us a vastly more diverse people than were our forefathers. They knew differences chiefly among Protestant sects. Today the Nation is far more heterogeneous religiously.... In the face of such profound changes, practices which may have been objectionable to no one in the time of Jefferson and Madison may today be highly offensive to many persons, the deeply devout and the nonbelievers alike. ${ }^{50}$

Thirty-six years later, the nation's religious diversity is even richer, and the potential interaction between government and religion even more extensive. Though blatant governmental regulation of religion is unlikely today, the complex network of state and federal laws still carries great potential for adversely affecting religious exercise or preferring some religions or religion generally.

Interpreting the First Amendment has proved vexing for courts, legislatures, and commentators. Especially problematic is the relation between the commitment to guard against government establishment of religion and the guarantee to protect individuals' freedom to exercise religion. Do the two clauses of the amendment have independent meaning, or do they modify one another? Restrictions on establishing religion could easily collide with assurances permitting the free exercise of religion. If a state cannot close schools and businesses on Sundays or Good Friday for fear of establishing Christianity as an official or preferred religion, that prohibition burdens individuals' abilities to observe their Sabbath and their holy days. If the state cannot exempt a synagogue from municipal historic preservation codes, then public rules may infringe on a religious group's self-government. If a public school denies funding and space to an Islamic student group while granting resources to a stress-reduction meditation group, it prefers one group while burdening another. If the state accommodates the free exercise needs of a student enrolled in a public school by creating a prayer rug room, it may risk advancing Islam over other religions. How should such collisions be treated under the law? Does the ban against establishment guard against government preference for

50. Id. at 240-41 (Brennan, J., concurring). 
any one religion, or for religion per se, as opposed to the secular? These questions remain open in contemporary jurisprudence, with clues provided only in the particular judgments of the courts. Simple guides or tests either fail to answer hard questions or else prove manipulable and unpredictable. Alternatives proposed by individual Justices and scholars fail to secure widespread support or to decide hard cases. ${ }^{51}$ In the areas of schooling and assistance to the poor, free exercise and establishment issues often arise together and require joint consideration.

Predicting the Supreme Court's interpretation of the religion clauses is especially difficult at this moment. Nonetheless, I engage in prediction. I also offer my own view about potential challenges to public subsidies for private religious schooling and governmental partnerships with private religious groups in the provision of welfare assistance, with a focus on the "charitable choice" provision of the Personal Responsibility and Work Reconciliation Act of $1996 .^{52}$

51. Phillip Kurland urges a position of strict neutrality, through which the government would use only secular criteria and would not undertake to accommodate religion. See Phillip J. Kurland, Of Church and State and the Supreme Court, 29 U. CHI. L. REV. 1, 5 (1961). Yet, this approach neglects the Free Exercise Clause. Laurence Tribe maintains that the two clauses advance voluntarism and separatism, see LAURENCE TRIBE, AMERICAN CONSTITUTIONAL LAW 1160-61 (2d ed. 1988), but the Supreme Court's decisions do not precisely fit these notions, see Geoffrey R. StONE ET AL., CONSTitutional LAW 1540-43 (3d ed. 1996) (describing the varying approaches the Supreme Court has taken to interpreting the religion clauses). Justice O'Connor has urged a notion of "no endorsement" to guide the application of the Establishment Clause. See, e.g., Capital Square Review and Advisory Bd. v. Pinette, 515 U.S. 750, 772-84 (1995) (O'Connor, J., concurring in part and concurring in the judgment) (arguing that the Establishment Clause should operate primarily to prevent government from endorsing a particular religion). Her idea, however, has received only limited support from the Court, with different Justices at times lining up behind it and at times against it. See, e.g., STONE ET AL., supra, at 1566-67 (discussing the "shifting" character of the majority that appears to endorse Justice O'Connor's endorsement test in County of Allegheny v. American Civil Liberties Union, 492 U.S. 573 (1989)). Furthermore, assessing what counts as a state endorsement of religion will vary with the perceptions of members of different groups. See MARTHA Minow, MaKing ALL THE DIFFERENCE: INCLUSION, EXCLUSION AND AMERICAN LAW 62-63 (1990) (suggesting that Justice O'Connor's endorsement test is hindered by the fact that it would be nearly impossible to find a truly objective observer who could neutrally determine whether a state action gave the appearance of endorsing religion). Lawrence Sager and Christopher Eisgruber have developed a coherent conception of the fundamental commitment to equal regard of all individuals behind the religion clauses, see, e.g., Christopher L. Eisgruber \& Lawrence G. Sager, Unthinking Religious Freedom, 74 TEX. L. REV. 577, 600-12 (1996), but to date this view has not attracted the support of the courts.

52. Pub. L. No. 104-193, § 104, 110 Stat. 2105, 2161-63 (1996) (codified at 42 U.S.C. 604(a)) (providing a mechanism by which states can contract with both secular and religious private organizations to provide social services) 


\section{A. Doctrinal Framework}

Despite its common use, the phrase "separation of church and state" neither appears in the First Amendment ${ }^{53}$ nor adequately summarizes the complex case law implementing the ban against governmental establishment of religion and the guarantee of religious free exercise. The much-battered doctrinal test for dealing with the governmental establishment of religion, developed by the Supreme Court in Lemon v. Kurztman, ${ }^{54}$ concedes that absolute separation between state and religious entities is not the goal of the First Amendment. ${ }^{55}$ The doctrinal test set forth by the Lemon Court considers: (1) whether the law or governmental action under question has a secular purpose; (2) whether the primary effects of law or government action advance or inhibit religion; and (3) whether the law or government action excessively entangles the government with religion. ${ }^{56}$ Note how this last prong admits that entanglement of some sort is not only permitted but expected.

However, Lemon has not supplied the basis for rejecting a law in over ten years, ${ }^{57}$ and at least five members of the Court think it

53. Thomas Jefferson is usually cited as the author of the notion that the First Amendment was intended to create "'a wall of separation between church and State."” Everson v. Board of Educ., 330 U.S. 1, 16 (1947) (quoting Reynolds v. United States, 98 U.S. 145, 164 (1878)). The Court itself has reasoned that total separation is not required, nor even possible. See Lynch v. Donnelly, 465 U.S. 668, 672-73 (1984) ("[A]s this Court has so often noted, total separation of [church and state] is not possible."); Committee for Pub. Educ. and Religious Liberty v. Nyquist, 413 U.S. 756, 760 (1973) ("It has never been thought either possible or desirable to enforce a regime of total separation [of church and state] .... .); Lemon v. Kurtzman, 403 U.S. 602, 614 (1971) ("Our prior holdings do not call for total separation between church and state; total separation is not possible in an absolute sense.").

54. 403 U.S. 602 (1971)

55. See id. at 614. Other thoughtful observers have noted the problems inherent in the idea of absolute separation. See, e.g., Ronald F. Thiemann, Religion in Public LifE: A DILEMMA FOR DEMOCRACY 42-66 (1996) (describing the idea of the separation of church and state as a "misleading metaphor"); Laura S. Underkuffler-Freund, The Separation of the Religious and the Secular: A Foundational Challenge to First Amendment Theory, 36 WM. \& MARY L. REV. 837 (1995) (arguing that separation of church and state is sometimes an analytical and practical impossibility).

56. See Lemon, 403 U.S. at 612-13.

57. Many scholars have commented on the Court's tendency to ignore Lemon. See, e.g., Rebecca Redwood French, From Yoder to Yoda: Models of Traditional, Modern, and Postmodern Religion in U.S. Constitutional Law, 41 ARIZ. L. REV. 49, 51 n.6 (1999) (describing Lemon as "roundly criticized and ignored in later [Supreme Court] opinions"); William P. Gray, Jr., The Ten Commandments and the Ten Amendments: A Case Study in Religious Freedom in Alabama, 49 ALA. L. REV. 509, 543 (1998) (noting that the Supreme Court seemed to disregard Lemon completely in deciding Lee v. Weisman, 505 U.S. 577 (1992)); Mardi L. Blis- 
should be replaced. ${ }^{58}$ The trend, if anything, is toward less stringent demands for separation of church and state than Lemon implied. ${ }^{59}$ For example, the Court in 1997 upheld the use of federal categorical funds to provide services on the site of a religious school to children otherwise eligible for federal services; this decision was a reversal of two prior Supreme Court decisions. ${ }^{60}$ The Court has not yet, however, rejected the Lemon test, nor has it approved an alternative single doctrinal framework. Justice Sandra Day O'Connor has proposed an alternative inquiry into whether the state's action could be viewed

sard, Note, Zobrest v. Catalina Foothills School District, 113 S.Ct. 2462 (1993): An Answered Prayer to Students with Disabilities in Religious Schools, 16 U. ARK. LiTTLE Rock L.J. 449, $472-73$ (1994) (arguing that the Supreme Court largely ignored Lemon in deciding Zobrest); Paula Savage Cohen, Comment, Psycho-Coercion, A New Establishment Clause Test: Lee v. Weisman and Its Initial Effect, 73 B.U. L. REV. 501, 501 (1993) (arguing the same about the Weisman decision); Shanin Revai, Note, County of Allegheny v. ACLU: Evolution of Chaos in Establishment Analysis, 40 AM. U. L. REV. 503, 519-20 (1990) (arguing that the Supreme Court applies Lemon inconsistently and occasionally seems to ignore it outright). State supreme courts finds themselves operating in the context of a reviewing court that has neither applied Lemon nor overruled it. See, e.g., Malyon v. Pierce County, 935 P.2d 1272, 1286 (Wash. 1997) (noting that the Supreme Court has declined to apply the Lemon test in recent cases, but holding that Lemon must still control Establishment Clause jurisprudence in Washington until the Supreme Court expressly overrules it).

58. Four Justices on the current Court have authored concurring or dissenting opinions calling for the rejection of the Lemon test, and a fifth, Justice Thomas, has joined in one of these opinions. See Lamb's Chapel v. Center Moriches Union Free Sch. Dist., 508 U.S. 384, 399-400 (1993) (Scalia, J., concurring).

59. Even the most stringent effort in that direction would have to engage the government in defining what counts and what does not count as religion. In the meantime, four of the current Supreme Court Justices have expressly called for replacing the Lemon test with an analysis that would be less hostile to government connections with religion. See, e.g., id. (Scalia, J., concurring) (proposing that the Lemon test be abandoned and listing opinions by four other current Justices who have, at one time or another, advocated doing so); County of Allegheny v. American Civil Liberties Union, 492 U.S. 573, 655-56 (1989) (Kennedy, J., concurring in part and dissenting in part) (arguing that the Lemon test is unduly hostile toward religion and should not be used as the primary guide for Establishment Clause jurisprudence). In recent opinions, some Justices invoke Lemon; others seek to replace it; and Justice O'Connor resists the notion of any "grand unified theories" in which bedrock principles collide. See Rosenberger v. Rector of the Univ. of Va., 515 U.S. 819, 852 (1995) (O'Connor, J., concurring) (arguing that Establishment Clause jurisprudence cannot be reduced to a single test). Yet, Justice O'Connor has led the Court toward another test for analyzing Establishment Clause claims, arguing that the Court should inquire into whether the government's action would be viewed by an objective observer as an endorsement of religion or of a particular religion. See, e.g., Capitol Square Review and Advisory Bd. v. Pinette, 515 U.S. 753, 773-78 (1995) (O'Connor, J., concurring) (advocating an endorsement test as an alternative to the plurality's free speech analysis of the constitutionality of a holiday display on state property).

60. See Agostini v. Felton, 521 U.S. 203, 215-36 (1997) (overruling Aguilar v. Felton, 473 U.S. 402 (1986), and, in relevant part, School Dist. v. Ball, 473 U.S. 373 (1986)). 
objectively as an endorsement of religion. ${ }^{61}$ Others emphasize the Constitution's purpose in preventing social or political division based on religious differences, ${ }^{62}$ or in ensuring governmental neutrality toward religion. ${ }^{63}$ Each of these approaches suggests more leniency toward what some might view as establishment problems.

Regarding the free exercise of religion, the Court's trend has been to reject challenges framed as burdens on the free exercise rights of minority religious groups and generally to shield government action that is couched in a general form. ${ }^{64}$ At the same time, the Court has relaxed previous restrictions on public funding where religious adherents seek public benefits available to others, in the name of preventing discrimination on the basis of religion. ${ }^{65}$ Several Justices

61. See Wallace v. Jaffree, 472 U.S. 38, 69 (1985) (O’Connor, J., concurring) (labeling her analysis an as "endorsement test" and asking whether the government has a purpose to endorse religion and whether the challenged statute conveys a message of state endorsement of religion). Richard Fallon notes that Justice O'Connor's endorsement test could lead to constitutional objection to voucher plans, although her opinion in Agostini did not allude to endorsement concerns and leaves open the possibility of approval of voucher plans. See Richard H. Fallon, Jr., Foreword: Implementing the Constitution, 111 HARV. L. REV. 56, 124 n.417 (1997).

62. See Bowen v. Kendrick, 487 U.S. 589, 610 (1988) (plurality) (holding that one purpose of the Establishment Clause is to limit government aid to "pervasively sectarian" religious organizations). In contrast, Lawrence Sager and Christopher Eisgrouper urge folding the religion clauses into a general constitutional commitment to equal regard. See Christopher L. Eisgruber \& Lawrence G. Sager, The Vulnerability of Conscience: The Constitutional Basis for Protecting Religious Conduct, 61 U. CHI. L. REV. 1245, 1282-1314 (1994). Sager further argues that this approach would protect members of religious minorities from discrimination, require publicly accessible reasons for defense of public programs, and also guard government actions of a general nature against challenges for burdening the exercise of religion. See Contemporary Challenges Facing the First Amendment Religion Clauses, 43 N.Y.L. SCH. L. REV. 101, 115-22 (1999) (remarks of Lawrence Sager).

63. See Carl H. Esbeck, A Constitutional Case for Governmental Cooperation with FaithBased Social Service Providers, 46 EMORY L.J. 1, 20-42 (1997) (arguing that a government policy of neutrality toward religion would encourage faith-based social service providers to better coordinate efforts with existing government programs). For a critique of this view as inadequately attentive to separationist concerns, see Douglas Laycock, The Underlying Unity of Separation and Neutrality, 46 EMORY L.J. 43 (1997).

64. See Lee v. Weisman, 505 U.S. 577, 587 (1992) (holding that, in some cases, the government may accommodate the free exercise of religion, so long as its actions do not tend to coerce anyone into supporting or participating in religious activity); County of Allegheny v. American Civil Liberties Union, 492 U.S. 573, 613-21 (1989) (plurality) (finding a state holiday display that included a Christmas tree and a menorah to be a permissible secular expression, and rejecting the argument that such a display impaired the free exercise rights of those who were neither Christian nor Jewish); see also Employment Div. v. Smith, 494 U.S. 872, 878 (1990) (finding the Free Exercise Clause is not violated by government requirements that are generally applicable, such as general criminal prohibitions).

65. See Bowen, 487 U.S. at 600-18 (affirming the constitutionality of a congressional act establishing a government program to provide funding to both religious and nonreligious 
make central to religion clause challenges an assessment of the potential coercion of the individual in the realm of religious belief or practice. ${ }^{66}$ Reaching conclusions on diverse grounds in particular cases, the Court seeks to steer a path between forbidden governmental establishment of religion and outlawed curbs on individuals' free exercise. More probative than any simple verbal formulation of the guiding principles for judgment are the actual actions taken by the Court in recent years. For example, in Larkin v. Grendel's Den, Inc., ${ }^{67}$ the Court struck down as unconstitutional a statute granting churches and schools the power to veto the grant of liquor licenses to restaurants within five hundred feet of church or school buildings. ${ }^{68}$ In a more tortured opinion in Board of Education of Kiryas Joel v. Gru$m e t,{ }^{69}$ the Court forbade New York from drawing school district lines to encompass only members of a particular religious group..$^{70}$ Thus, one line of analysis asks whether the government has delegated a public function to a religious group. Granting churches vetoes over liquor licenses to nearby restaurants and creating a special school district for a religiously identified community cross into this forbidden zone.

In the context of public schools and aid to private schools, no discernible pattern has appeared in the Supreme Court's decisions affecting public financial support for activities related to private parochial schooling. A particular tangle of cases approved some kinds of tax assistance and reimbursements for parochial school tuition but disapproved of others. ${ }^{71}$ These cases suggest that universally available

groups for services and research related to adolescent sexual relations).

66. For example, the plurality opinion in Weisman, written by Justice Kennedy, found that prayers offered during a public school graduation amount to an Establishment Clause violation because of the risk of religious coercion. See Weisman, 505 U.S. at 593 (plurality). Justice O'Connor's majority opinion in Lyng v. Northeast Indian Cemetary Protective Ass'n, 485 U.S. 439 (1988), considered the potential coercion of individuals in the course of analyzing a free exercise challenge. See Lyng, 485 U.S. at 449. For a discussion of the plurality view in Weisman, see Elizabeth B. Brandy, Lee v. Weisman: A New Age for Establishment Clause Jurisprudence?, 23 Golden Gate U. L. REV. 535, 558-62 (1993). Free exercise of religion may be burdened even by indirect coercion, see Lyng, 485 U.S. at 450, but there may be no constitutional violation if the government's requirements are generally applicable, as with a general criminal prohibition, see Smith, 494 U.S. at 878.

67. 459 U.S. 116 (1982).

68. See id. at 117.

69. 512 U.S. 687 (1994)

70. See id. at 696.

71. Thus, the Court has summarily affirmed several cases in which lower courts rejected tax credits or deductions to assist parents whose children attend nonpublic schools. See Public 
assistance, including aid to families using religious schools, have a greater chance of surviving challenges. Indeed, the Supreme Court has found that programs neutrally providing governmental assistance to a broad spectrum of citizens are more acceptable than programs assisting only some parents, or only parents pursuing sectarian schools. $^{72}$ Thus, public subsidies for textbooks used by students, regardless of their attendance at public or private schools, have been ruled constitutional. ${ }^{73}$ Also passing constitutional muster is the use of public funds to support transportation of children to parochial schools. ${ }^{74}$ Public employees can provide remedial instruction and counseling to students on the site of parochial schools. ${ }^{75}$ Yet, a state cannot supplement the salaries of teachers at nonpublic schools to approximate the salaries of public school teachers. ${ }^{76}$

Funds for Pub. Sch. v. Byrne, 590 F.2d 514 (3d Cir.) (holding the same for an educational deduction from state tax), aff'd mem. sub nom. Beggans v. Public Funds for Pub. Sch., 442 U.S. 907 (1979); Kosydar v. Wolman, 353 F. Supp. 744 (S.D. Ohio 1972) (finding unconstitutional a state educational tax credit that was found to benefit primarily students attending private sectarian religious schools), aff'd mem. sub nom. Grit v. Wolman, 413 U.S. 901 (1973). In a full opinion, the Court struck down as unconstitutional a New York state tuition grant and tax benefit program for low-income parents because the program operated primarily to subsidize private sectarian religious schools. See Committee for Pub. Educ. v. Nyquist, 413 U.S. 756 (1973). The Court dismissed arguments that the statute was constitutional because grants were delivered to parents rather than to schools, emphasizing that "the fact that aid is disbursed to parents rather than to the schools is only one among many factors to be considered [in evaluating the constitutionality of a state law]." Id. at 781. As indicated by my analysis below, I think that the current Court would give greater weight to this one factor. For example, in a subsequent case, the Court approved a state provision allowing parents to deduct from their state income taxes certain expenses relating to transportation, tuition, and textbooks in support of their children's schooling. See Mueller v. Allen, 463 U.S. 388, 393-405 (1983). The Court did note that the Mueller statute was "vitally different from the scheme struck down in Nyquist," id. at 399 , in that the tax deduction in question was available to all parents, not just those whose children were attending private schools, see id. at 397-99.

72. See Mueller, 463 U.S. at 397-99; Nyquist, 413 U.S. at 775-76.

73. See Wolman v. Walter, 433 U.S. 229, 238 (1977) (approving public funding for textbooks, testing and scoring, diagnostic services, and therapeutic services in nonpublic schools, but striking down public funding for instructional materials and field-trip services); Meek v. Pittenger, 421 U.S. 349, 362 (1975) (upholding a textbook loan program to nonpublic schools, as it "'merely makes available to all children the benefits of a general program to lend school books free of charge."” (quoting Board of Educ. v. Allen, 392 U.S. 236, 243-44 (1968))).

74. See Everson v. Board of Educ., 330 U.S. 1, 17-18 (1947) ("The First Amendment has erected a wall between church and state. The wall must be kept high and impregnable. We could not approve the slightest breach. New Jersey has not breached it here.").

75. See Agostini v. Felton, 521 U.S. 203, 240 (1997). Agostini overruled the Supreme Court's earlier decisions of Aguilar v. Felton, 473 U.S. 402 (1985), and School District v. Ball, 473 U.S. 373 (1985).

76. See Lemon v. Kurtzman, 403 U.S. 602, 606-07 (1971). 
The Supreme Court has moved toward permitting state financial assistance to students in parochial schools. In addition, the Court treats the private choice of parents and students as an act that severs any prohibited connection between the public funds and the religious institution. Thus, the Court recently ruled that a state can pay a blind student's tuition at a sectarian theological institution through generally applicable financial aid programs, because the public funds are paid directly to the student, who then transmits them to the educational institution of his choice. ${ }^{77}$ Similarly, a state may allow taxpayers to deduct from their state income taxes certain expenses incurred in providing education for their children, despite objections that this provision has the effect of advancing the sectarian aims of nonpublic schools. $^{78}$ Federal funds to assist students with disabilities, students from low-income communities, and students identified as presenting special risks of school failure may be used on the site of religious schools when they are distributed through a public agency to the eligible students, regardless of where the students choose to attend school. ${ }^{79}$ Public provision of a sign language interpreter in a pervasively sectarian school does not violate the Establishment Clause. ${ }^{80}$ Apparently, the parents' choice of a religious school should not deprive the student of services available to public school students. Additionally, monies generally available to support student speech on

77. See Witters v. Washington Dep't of Servs. for the Blind, 474 U.S. 481, 487 (1986) ("Any aid provided under Washington's program that ultimately flows to religious institutions does so only as a result of the genuinely independent and private choices of aid recipients."). In Witters, the Court drew an explicit distinction between that case and Ball: "[W]here... no meaningful distinction can be made between aid to the student and aid to the school, 'the concept of a loan to individuals is a transparent fiction."' Id. at 487 n.4 (quoting Ball, 473 U.S. at 396). The Court recently restated and reaffirmed this view of the case in explaining that "any money that ultimately went to religious institutions did so "only as a result of the genuinely independent and private choices of' individuals." Agostini, 521 U.S. at 226 (quoting Witters, 474 U.S. at 487).

78. See Mueller v. Allen, 463 U.S. 388, 402 (1983) (finding no Establishment Clause violation in a state law allowing income tax deductions for educational expenses including tuition, textbooks, school supplies, and transportation for parents whose children attend elementary or secondary school).

79. See Zobrest v. Catalina Foothills Sch. Dist., 509 U.S. 1, 3 (1993) (holding that the Establishment Clause does not prohibit a school district from providing a sign language interpreter for a deaf student attending a Roman Catholic high school); Witters, 474 U.S. at 482 (finding no state endorsement of religion in extending assistance to a blind person studying at a Christian college, even if the student is pursuing a career in ministry). Notably, the Court did not use the Lemon test in the Zobrest decision.

80. See Zobrest, 509 U.S. at 3. 
the campus of public universities must be available to support religious speech. ${ }^{81}$

Though a certain program may be constitutional on its face, the actual implementation of the program may violate the Constitution. This allows the Court to distinguish facial challenges to programs permitting the use of public funds in religious organizations from "asapplied" challenges to the actual operation of such programs. In $\mathrm{Bo}$ wen $v$. Kendrick, ${ }^{82}$ for example, the Court rejected a facial challenge to statutory authorization for federal grants to public and private organizations, including religious ones, to assist counseling and research in the area of premarital adolescent sexual relations. ${ }^{83}$ The Court nonetheless remanded the case for a factual finding about the actual uses of the monies and indicated that the grants might be unconstitutional if the funds assisted "pervasively sectarian" institutions or paid for "specifically religious activity in an otherwise substantially secular setting." " ${ }^{84}$ Thus, the Court acknowledged that constitutional violations can arise with particular uses of public dollars to support religious institutions, even though it generally permits religious entities to participate in universally available grant programs. Perhaps, in the Court's view, the dangers of intergroup conflict seem more remote when religious groups are allowed to participate in universally available grant programs than when they are excluded from them.

\section{B. Applications}

The Supreme Court's recent jurisprudence suggests that government programs using public funds to pay religious school tuitions will be upheld as constitutional, while government efforts to share or to turn over responsibilities in the welfare area to religious entities may be unconstitutional. The following discussion offers some words of prediction and recommendation regarding both school and welfare vouchers.

81. See Rosenberger v. Rector of the Univ. of Va., 515 U.S. 819, 840 (1995). The Court emphasized that the funds at issue came from a student activity fee, not from a general tax, and refrained from extending its analysis to expenditure from a general tax fund. See id. at 840-41.

82. 487 U.S. 589 (1988)

83. Id. at 593; see also id. at 617 ("[T]he statute has a valid secular purpose, does not have the primary effect of advancing religion, and does not create an excessive entanglement of church and state.").

84. Id. at 613 (quoting Hunt v. McNair, 413 U.S. 734, 743 (1973)). 
1. School-Choice Programs. ${ }^{85}$ Like tax deductions for school tuition and expenses, tax breaks on education savings plans, and publicly funded scholarships, school vouchers divert public funds to private schools. ${ }^{86}$ Because the vast majority of private schools are religiously affiliated, these programs may create impermissible entanglements between religion and the state. ${ }^{87}$ Three cases recently considered by state courts highlight this issue. The Cleveland City School District case arose when a federal district court in the city found the quality of the public schools so poor that it ordered the

85. School-choice programs that restrict vouchers for use in nonreligious schools do not raise problems under the Establishment Clause, but they can be challenged as interfering with the free exercise of religion by those parents who wish to elect parochial schools. Thus far, such challenges have had more success in law reviews than in the courts. Compare Michael McConnell, The Selective Funding Problem: Abortions and Religious Schools, 104 HARV. L. REV. 989, 1014-22 (1991) (arguing that the government cannot penalize the exercise of constitutional rights and explaining that "[b]y exercising their constitutional right to introduce a religious element into their child's education at their own expense, a family forfeits their entitlement to the largest and most important benefit provided by the state for its people"), and Michael McConnell, Education Disestablishment: Why Democratic Values Are Ill-Served by Democratic Control of Schooling, Presentation to the American Society of Political and Legal Philosophers (Dec. 1998) (forthcoming in NOMOS) [hereinafter McConnell, Education Disestablishment] (arguing that exclusion of religious schools from choice programs violates the Free Exercise Clause), with Bagley v. Raymond Sch. Dep’t, 728 A.2d 127, 135 (Me. 1999) (finding no free exercise violation in the exclusion of religious schools from a choice program), and Chittenden Town Sch. Dist. v. Vermont Dep't of Educ., No. 97-275, 1999 WL 378244 (Vt. June 11, 1999) (rejecting a claim that the denial of public funds for use at parochial schools would contravene individuals' right to the free exercise of religion). School-choice programs such as magnet and charter school programs expand choice among public schools and do not seem to impinge upon the religion clauses of the First Amendment

86. Of course, it is a matter of some dispute whether tax deductions and tax credits amount to public funds or merely to the preservation of private funds. However, in a strict economic sense, they deduct monies that otherwise would be collected and put into the public fisc. See Texas Monthly, Inc. v. Bullock, 489 U.S. 1, 14-17 (1989) (plurality) (holding that an exclusive exemption for religious publications from sales and usage tax lacks sufficient breadth to pass "Establishment scrutiny"). Taking the private funds perspective, some commentators have argued that parents who send their children to parochial schools are unfairly forced to pay tuition twice-once through taxes that support only public schools, and once in tuition paid directly to the parochial schools. The central defect in this argument is that not only parents of school-aged children are taxed to support public schools. Public schools are a public good, and all taxpayers therefore invest in the education of the next generation on the premise that the results will make everyone better off. A contrasting and more powerful argument can be made that provision of a voucher program that covers private but not religious schools risks invidious discrimination against those who would choose religious schools.

87. See, e.g., Green, supra note 12, at 57-73 (describing potential Establishment Clause problems); Walter McCann \& Judith Areen, Vouchers and the Citizen-Some Legal Questions, in EduCATIONAL Vouchers: CONCEPTS AND CONTROVERSIES 117-24 (George R. LaNoue ed., 1972) (same) 
state to take them over. ${ }^{88}$ In response, the state initiated a scholarship program to permit students to attend neighboring public schools and registered private schools. ${ }^{89}$ Some eighty percent of the private schools registered for the 1996-97 school year were sectarian; no neighboring public school districts participated. ${ }^{90}$ A taxpayer group filed suit alleging that the program violated both the federal and state constitutions, and the state court of appeals agreed. ${ }^{91}$ The Ohio Supreme Court, however, ruled that the school voucher program did not violate the Establishment Clause, except where selection criteria gave priority to students whose parents belonged to the religious group supporting the sectarian school. ${ }^{92}$ Finding these selection criteria severable from the statutory scheme, the court rejected the remaining federal constitutional challenges, ${ }^{93}$ while at the same time ruling that the statute violated the "one subject per statute" requirement in the state constitution. ${ }^{94}$ This technical problem was fixed by the legislature in early $1999 .{ }^{95}$ On August 25, 1999, a federal district court enjoined the voucher program on Establishment Clause grounds. ${ }^{96}$ After waves of public concern over halting a school program just as the school year was starting, the district court stayed its order as to already-enrolled students. ${ }^{97}$

The Milwaukee Parental Choice Program, initiated in Wisconsin in 1989, was amended in 1995 to allow up to fifteen percent of the low-income students in that city's public system to attend private schools, including religious schools. ${ }^{98}$ In 1995, eighty-nine of the 122 private schools eligible for the program were sectarian. ${ }^{99}$ A state trial

88. See Simmons-Harris v. Goff, Nos. 96APE08-982, 96APE08-991, 1997 WL 217583, at *1 (Ohio Ct. App. May 1, 1997), aff'd in part and rev'd in part, 711 N.E.2d 203 (Ohio 1999).

89. In 1996-97, scholarship recipients received $90 \%$ of tuition costs, up to a maximum of \$2500. See id.

90. See id.

91. See id.

92. See Goff, 711 N.E.2d at 210.

93. See id.

94. See id. at 210-16.

95. See Simmons-Harris v. Zelman, 54 F. Supp. 2d 725, 728 (N.D. Ohio 1999).

96. See id. at 741; see also Amy Dockser Marcus, Judge Blocks School Voucher Program in Ohio, WALl St. J., Aug. 25, 1999, at B2.

97. See Simmons-Harris v. Zelman, Nos. 1:99 CV 1740, 1:99 CV 1818, 1999 WL 669222, at *2 (N.D. Ohio Aug. 27, 1999).

98. See Jackson v. Benson, 578 N.W.2d 602, 608 (Wis.), cert. denied, 119 S. Ct. 466 (1998). In order to participate in the program, the private schools must agree to follow guidelines prohibiting discrimination and promoting health and safety. See id.

99. See id. at 619 n.17. 
court enjoined the plan's implementation on Establishment Clause grounds, but the Wisconsin Supreme Court upheld the constitutionality of the program even though religious schools are the likely beneficiary of most of the public funds. ${ }^{100}$ The United States Supreme Court later declined to review this decision, ${ }^{101}$ appearing to signal a green light to such experiments at the state level without giving explicit federal constitutional approval. ${ }^{102}$

In Vermont, the town of Chittenden authorized the payment of private school tuitions for its resident children in 1995, since the town did not have its own high school. ${ }^{103}$ The Vermont Department of Education, however, disapproved of the town's plan to pay tuition to a nearby Catholic academy and threatened to deny Chittenden all educational funding. ${ }^{104}$ The Vermont Supreme Court, declining to use an Establishment Clause rationale, ruled that the town's plan violated the "compelled support" clause of the state constitution, which forbids state support of religious worship. ${ }^{105}$

100. See id.

101. See Jackson v. Benson, 119 S. Ct. 466 (1998).

102. The Wisconsin court reasoned that there was a secular purpose of advancing parental choices in education without entangling the government in religious schools themselves. See Jackson, 578 N.W.2d at 620 . It also concluded that the primary effect of the program was not to benefit religious schools but instead to enhance genuinely independent and private parental choices. See id. at 617-19. Critics of the opinion charge that the Wisconsin court neglected federal precedents forbidding foreseeable financial support for private religious institutions and banning governmental endorsement of religious means where secular means would suffice. See Case Comment, Establishment Clause-School Vouchers-Wisconsin Supreme Court Upholds Milwaukee Parental Choice Program, 112 HARV. L. REV. 737, 742 (1999) (disagreeing with the court's decision to uphold the choice program because it ignored precedent and allowed an "entanglement" of church and state by enabling religious schools to become dependent on the government).

103. See Chittenden Town Sch. Dist. v. Vermont Dep’t of Educ., No. 97-275, 1999 WL 378244 (Vt. June 11, 1999).

104. See id.

105. See id. The state constitution's chapter I, article 3 provides:

That all persons have a natural and unalienable right, to worship Almighty God, according to the dictates of their own consciences and understandings, as in their opinions shall be regulated by the word of God; and that no person ought to, or of right can be compelled to attend any religious worship, or erect or support any place of worship, or maintain any minister, contrary to the dictates of conscience, nor can any person be justly deprived or abridged of any civil right as a citizen, on account of religious sentiments, or peculiar mode of religious worship; and that no authority can, or ought to be vested in, or assumed by, any power whatever, that shall in any case interfere with, or in any manner control the rights of conscience, in the free exercise of religious worship.

VT. CONST. ch. I., art. 3. The analysis in the text of this Article addresses the federal Constitution. State bans against the flow of public dollars into religious entities may prove a greater obstacle to voucher programs that include religious schools (or to arguments that such schools 
Given this history, I predict that the courts will assess constitutional challenges to school choice by looking to the chain of decisionmaking afforded under the program. ${ }^{106}$ If the actual decision about where to spend the governmental money is given to private actors, such as parents and students, these programs can plausibly be understood as enhancing private choices in education rather than establishing religion through governmental means. This characterization would seem to satisfy the Lemon test: the purpose of promoting parental choice to improve education is a secular one, the primary effect arguably is to enhance competition and therefore overall educational quality, ${ }^{107}$ and entanglement between church and state can be minimized if funds pass from the state, to parents, to private schools. Moreover, if these opportunities for school choice are afforded to all parents and students, it could not be said that the government was favoring only certain groups. ${ }^{108}$ The legal system comfortably adopts this view about parents in other contexts. For example, a parent's decision to refuse medical treatment for a hospitalized child does not trigger any liability on the hospital because the treatment decision is made by the parents.

Indeed, if a state institutes a school voucher program allowing private selection of private schools, the program may be required to extend to religious schools. Otherwise, those who prefer religious schools could plausibly claim discrimination in public programs, amounting to a burden on their free exercise of religion or a violation of the Equal Protection Clause. ${ }^{109}$ Crucial to sustaining such claims,

must be eligible for vouchers). Yet, the federal equal protection guarantee remains a further resource for those worried about the exclusion of religious schools from voucher programs.

106. The Court's majority stated in Mueller: "It is noteworthy that all but one of our recent cases invalidating state aid to parochial schools have involved the direct transmission of assistance from the state to the schools themselves." Mueller v. Allen, 463 U.S. 388, 399 (1983). The one exception was Nyquist, which the Court distinguished on the ground that the benefits were available only to parents of children in nonpublic schools. See id. at 398.

107. Note that a serious problem could emerge under the effects prong of the test if all or even most of the vouchers were used in one parochial school or system. See infra notes 112-14 and accompanying text (discussing nonfacial challenges).

108. See Mueller, 463 U.S. at 398 (approving a tax deduction for educational expenses, in part because of its availability to "all parents").

109. Some challengers may oppose any voucher or tax plan that assists only those who elect private schools, rather than equally assisting those in public and private schools. They would point to the Court's emphasis on this factor in approving the tax deduction scheme in Mueller. See id. It would indeed be a new step for the Court to approve a voucher or tax relief provision that did not afford benefits equally to parents who select public schools and parents who pick private schools for their children. However, I do not think that this step can be opposed suc- 
though, is the retention of public and nonsectarian schools as alternatives. The very success of parochial schools no doubt has something to do with their ability to select and to exclude; $;^{110}$ the constitutionality of voucher plans that include such schools depends on the presence of genuine alternatives. ${ }^{11}$

The constitutional challenge most likely to succeed would attack the way in which a school voucher program is applied, not designed. If all or most of the vouchers were used to select religious schools, especially if those religious schools were largely or exclusively of a single denomination, the voucher program might raise concerns similar to those the Supreme Court addressed in Bowen v. Kendrick. ${ }^{112}$ Discerning such effects would require a factual finding about the actual operations of the scheme. However, mere disparities between the number of religious schools receiving vouchers and the number of secular private schools receiving vouchers would not convince the Supreme Court that an Establishment Clause problem existed. Indeed, the Court has held that any unequal effect of a public program assisting private school choice "can fairly be regarded as a rough return for the benefits ... provided to the state and all taxpay-

cessfully by asserting that parents who send their children to public school get the direct benefit of their tax contributions to those schools, while parents who send their children to private schools do not. This consumer conception of taxation misconstrues the nature and purpose of public support of schools, for even adults who have no children of school age must pay such taxes. They support the public good of developing an educated populace. In the meantime, the line of cases decided by the Court since Mueller, described above, suggests the growing solicitude of the Court toward not just private educational choices, but also religious ones. See supra notes 71-81 and accompanying text. Moreover, at a sufficient level of generality, private school vouchers and tax relief programs can be viewed as benefiting all parents-for all parents potentially could opt for private schools. In addition, the Court reasoned in Mueller that any disparate benefit flowing to parochial schools can be regarded as a return for the benefits provided to the state and to taxpayers from the parochial school option. See Mueller, 463 U.S. at 402.

110. See Donald L. Beci, School Violence: Protecting Our Children and the Fourth Amendment, 41 CATH. U. L. REV. 817, 823 n.31 (1992) (noting that private schools can exclude disruptive students by means of their selection processes); Julie Huston Vallarelli, Note, State Constitutional Restraints on Privatization of Education, 72 B.U. L. REV. 381, 387 (1992) (observing that private schools may exclude students through suspensions or expulsions without observing the due process restraints imposed on public schools). Private schools may not discriminate on the basis of race, see Runyon v. McCrary, 427 U.S. 160, 179 (1976) (applying 42 U.S.C. § 1981 to private schools), but they may discriminate on other factors, such as economic class. With the exception of limited scholarship programs, private schools largely restrict themselves to students with the ability to pay tuition.

111. See Isaac Kramnick \& R. Laurence Moore, Can the Churches Save the Cities?: FaithBased Services and the Constitution, AM. ProsPeCt, Nov.-Dec. 1997, at 47; see also Minow, Reforming School Reform, supra note 3.

112. 487 U.S. 589 (1988) 
ers by parents sending their children to parochial schools." ${ }^{\text {113 }}$ In so doing, the Court emphasized that it "would be loath to adopt a rule grounding the constitutionality of a facially neutral law on annual reports reciting the extent to which various classes of private citizens claimed benefits under the law." 114 So long as a public, nonreligious option remains available, providing school vouchers to help pay for religious school tuitions seems compatible with the emerging Court treatment of religion.

Alternatively, a constitutional analysis quite different from the conventional practice of courts and commentators could pose a profound challenge to vouchers and tax relief assisting private school choice. Conventional constitutional interpretation, combining evidence of the intentions of the drafters of the First Amendment and analogies to prior Supreme Court interpretations of the Amendment's Establishment and Free Exercise Clauses, forbids schemes giving public dollars to parents to elect from among a range of public and private schooling options. However, neither of these sources provides a convincing basis for rejecting public financial support for parental choice over schooling, given the Framers' commitment to education as a means for developing children's capacities to know the Bible ${ }^{115}$ as well as the pattern of Supreme Court precedents I have just described. An alternative constitutional interpretation would instead ask whether a set of social changes could so alter the assumptions underlying the context in which the Constitution operates as to place its premises in jeopardy. ${ }^{116}$ Under this untried method of inter-

113. Mueller, 463 U.S. at 402.

114. Id. at 401; see also Agostini v. Felton, 521 U.S. 203, 229 (1997) ("Nor are we willing to conclude that the constitutionality of an aid program depends on the number of sectarian school students who happen to receive the otherwise neutral aid.").

115. See John W. Whitehead, The Separation Illusion: A Lawyer Examines the FIRST AMENDMENT 88 (1977) (observing that the Framers of the First Amendment intended to "leave the states a free hand in religion-free to establish their churches, free to permit Bible reading and prayer in the schools"). The Framers no doubt followed the colonial conception of schools as vehicles for preserving both religious faith and existing economic and social hierarchies. See Merle Curti, The Social IdEAS of AMERICAN EduCATORS 4-5, 10, 16 (1974). Of course, the relationship between the states and the federal Constitution has changed profoundly since the Civil War and the New Deal.

116. Many constitutional scholars have argued that constitutional interpretation is inevitably affected by events occurring long after the Constitution's adoption. See, e.g., 1 BRUCE Ackerman, We the People: Foundations (1991); 2 Bruce Ackerman, We the People: TRANSFORMATIONS (1998); SANFORD LEVINSON, CONSTITUTIONAL FAITH (1988); Lawrence Lessig, Fidelity and Constraint, 65 Fordham L. REV. 1365 (1997) [hereinafter Lessig, Fidelity and Constraint]; Lawrence Lessig, Fidelity in Translation, 71 TEX. L. REV. 1165 (1993). For a 
pretation, television might warrant a reconsideration of what constitutes constitutional speech and political campaign practices; cyberspace might require reevaluation of property and jurisdictional rules; and the diversion of public dollars from public to private schools might require reassessment of the preconditions for a committed, tolerant, and equal citizenry. ${ }^{117}$ Calling for a kind of holistic assessment of the Constitution's guarantees and preconditions, this mode of interpretation would also elevate facts about social change. Nevertheless, no such constitutional interpretation currently guides any court, and it is not my purpose here to propound and defend this alternative approach.

Absent such an analysis, we are left with debates over policy. First, would the inclusion of religious schools in voucher programs facilitate or undermine the important goal of preparing each successive generation for democratic self-governance, as well as fostering the requisite qualities of tolerance, civic duty, and social cooperation? Many people think that the nation has much to benefit from private parochial schools and experiments enabling more parents to opt for them. ${ }^{118}$ For example, a recent book argues that Catholic schools are more successful at fostering human cooperation than public schools, though public schools often were founded for that very purpose. ${ }^{119}$ This may occur because Catholic schools are devoted to the purpose of promoting human cooperation for the common good and ground their work in a moral base with experienced teachers, communal organization, and a capacity to engage teachers and students. ${ }^{120}$ Yet,

thoughtful overview of the dimensions of selecting a constitutional theory-and the unavoidable role of factors external to the Constitution-see Richard H. Fallon, Jr., How to Choose a Constitutional Theory, 87 CAL. L. REV. 535 (1999). On occasion, scholars call for reassessing existing constitutional commitments in light of notable social, economic, or technological changes. See Lessig, Fidelity and Constraint, supra; see also J. M. Balkin, Some Realism About Pluralism: Legal Realist Approaches to the First Amendment, 1990 DUKE L.J. 375.

117. Contrary to my own view, Michael McConnell challenges the premise that the common school, whether in the ideal or in practice, could ever serve this function. See McConnell, Education Disestablishment, supra note 85. Either the school will assume some non-neutral stance toward values (preferring, for example, Protestantism or secular humanism), or it will avoid the task of inculcating values and thereby disserve society. See id.

118. See BRYK ET AL., supra note 37, at 343 (suggesting a reconsideration of the strict exclusion of public support for religious schools after examining how other countries handle this separation); CHUBB \& MoE, supra note 3, at 206-19, 221-23, 225-29 (presenting a design of and support for a choice system that would not "privatize" the nation's schools, but rather would create a "truly public system - and a democratic one").

119. See BRYK ET AL., supra note 37, at 11,327.

120. See id. However, cooperation and service are not the same as civic-mindedness. For 
even if we admire the accomplishments of parochial schools and their capacity to produce both good standardized test results and students imbued with a sense of purpose and coherent values, the mission of schooling in a democracy calls for inculcating certain public norms necessary to foster democracy. ${ }^{121}$ Neutrality in message is neither possible nor desirable, but inculcation of the civic values of tolerance, equality, liberty, and democracy is defensible in a nation committed to and dependent upon these values. Schools that model these ideas are more likely to inculcate these values than schools departing from them. Such a model is best provided by the common public school, the school system intended to afford children from all walks of life equal opportunities and a shared experience, ${ }^{122}$ even if a small percentage of families exercise their constitutionally protected right to elect religious or other private alternatives. ${ }^{123}$ Regrettably, the goal of the common school is a waning ideal, not a description of wide practice. Public schools across the country are marked by notable disparities in racial balance, and those disparities, sadly, track differences in school quality. Disparities in the quality of instruction mark divisions between white students and all others. ${ }^{124}$ Social class and racial segre-

this reason, even private schools that cultivate a strong sense of collaboration and service do not initiate students into the conception of civic engagement and dialogue modeled by the ideal of public schools. See John Dewey, Outlines of A Critical TheORY of ETHICs 131 (Hillary House, Inc. 1957) (1891) (arguing that education should take place in an atmosphere enabling equal self-realization of each individual in the community); JOHN DEWEY \& EVELYN DEWEY, SCHOOLS OF TOMORROW 313-16 (1915) (arguing that the school itself should reconstruct society and break down barriers between economic and social classes); John Dewey, Philosophy and Education, in Higher EdUCATION FACES THE FUtUre 273, 282 (Paul A. Schilpp ed., 1930) (arguing that education needs to remake social conditions).

121. See AsSOCIATION fOR SUPERVISION AND CURRICUlum DEVElopment, ISSUES ANALYSIS: PUblic SCHOOLS OF CHOICE 9 (1990) (noting that the public good is created by "common learnings such as citizenship, enculturation, and interpersonal relations in a pluralistic society"); Robert B. Westbrook, Public Schooling and American Democracy, in DEMOCRACY, EDUCATION, AND THE SCHOOLS 125, 131 (Roger Soder ed., 1996) (recognizing that common schooling was designed to produce a shared experience among children of different classes).

122. See Richard Pratte, The Public School Movement 75-124 (1973) (examining the origin, history, and ideology of the public school movement in America, as well as the economic and social forces that are challenging it); DAVID TYACK \& ELIZABETH HANSOT, MANGers of Virtue: Public SCHOOL LeADERSHIP IN AMERICA, 1820-1980, at 20-25 (1982) ("In public schools ... in nineteenth century America no sharp lines separated religion, citizenship, and economic enterprise.").

123. See Pierce v. Society of Sisters, 268 U.S. 510, 534-35 (1925) (holding that a child is "not a mere creature of the state" and that parents therefore have a right to direct the education of their offspring).

124. See Gary Orfield et AL., Dismantling Desegregation: The Quiet Reversal 
gation thus impair the ideal of the common school. The real or perceived failure of so many public schools to afford genuine chances for education, especially in large urban districts, makes the turn toward competition in education a plausible, if not urgent, public policy development. ${ }^{125}$ Unfortunately, this very turn risks drawing so many students away from the public schools that the common school ideal will have no chance. An experiment should seek to strengthen, not to destroy common public schools.

This potential dilemma points to a second policy concern. Will inclusion of religious schools in voucher programs lead to such an exodus of motivated parents and children that the prospects for improving public schools will disappear? The flip side of this question is whether exclusion of religious schools from voucher programs will trap many children in failing public schools, despite the chance for a better education in neighboring religious schools. Resolving these problems involves a difficult balancing of competing values, as well as alternative views about what students and the nation need.

Finally, there is the policy question of whether religious schools indeed can better educate those who currently remain in substandard or failing public schools. It would be an enormous mistake to think that parochial schools or school-choice proposals can solve the problems of schooling for all of America's children. It is impossible to disentangle the success of parochial schools in retaining children from at-risk backgrounds and in generating good test scores from both the schools' ability to exclude and expel troublesome students and the involvement of the parents who select such schools. ${ }^{126}$

The belief that competition itself will elevate the quality of all schools has yet to be demonstrated by any system that has adopted

OF BROWN V. BOARD OF EDUCATION 359-61 (1996) (discussing how resegregation has spread across the country). Overcoming education disadvantages for poor and minority children will require multiple kinds of reform. See DAVID A. HAMBURG, TODAY's ChILDREN: CREATING A FUTURE FOR A GENERATION IN CRISIS 296-323 (1992)

125. See, e.g., CARnegie Corporation of NeW York, Years of Promise: A COMPREHENSIVE LEARNING STRATEGY FOR AMERICA'S CHILDREN (1997); ERIC HANUSCHEK ET AL., MAKING SChOOls WORK: IMPROVING PERFormance AND CONTROLling COSTS xvii-xviii (1994); ORGANISATION FOR ECONOMIC CO-OPERATION AND DEVELOPMENT, OECD ECONOMIC SURVEYS: United STATES 52 (1993).

126. See Arthur S. Goldberger \& Glen G. Cain, The Causal Analysis of Cognitive Outcomes in the Coleman Hoffer and Kilgore Report, 55 Soc. OF EDUC. 103, 103-22 (1982); Willms, supra note 20, at 113 (comparing the growth in academic achievement of public- and Catholic-school students and concluding that "policy decisions should not be based on the assumption that either public or private schools produce better achievement outcomes"). 
charter or magnet schools. Increasingly, even those "public" choice options will include schools run under contract by private, often untested, management. ${ }^{127}$ The deep problems of public education in America ultimately are intertwined with longstanding, complex problems in families and communities, and with skewed economic opportunity structures. The immediate consequence of school-choice programs will most likely leave the most vulnerable children from the least-engaged and least-solid families in the worst schools. ${ }^{128}$ The solution of school choice-either inside public systems or crossing over to private schools-is worth exploring, but only as one of many strategies to improve the real opportunities for all children. ${ }^{129}$

2. "Charitable Choice." The charitable choice provision of the Personal Responsibility and Work Opportunity Reconciliation Act of $1996^{130}$-more commonly known as the Welfare Reform Act, or "the act ending welfare as we knew it"-is more vulnerable to a constitutional challenge, but, in my view, it is less troubling on policy grounds. The provision authorizes the states to pay religious agencies directly for providing federally funded welfare services and to create vouchers that enable individual aid recipients to receive welfare services from a number of private nonprofit agencies approved by the state. ${ }^{131}$ By selecting religious agencies for these purposes, states may

127. See Note, The Hazards of Making Public Schooling a Private Business, 112 HARV. L. REV. 695, 695-96 \& n.6 (1999) (“A market delivery approach, which displaces government control, has even extended an opportunity for profit-seeking enterprises to enter a realm traditionally occupied by public and nonprofit providers.").

128. See Minow, Reforming School Reform, supra note 3, at 281 ("A choice system will make the inequalities among parents directly cost children currently enrolled in public schools.").

129. See id. at 42-45 (recommending that school reform include modification of existing options, such as charter schools).

130. 42 U.S.C. $\$ 604 a$ (Supp. 1997).

131. See id. $\S 604 a(a)(1)$. An additional feature of charitable choice may lead to a legal challenge. Stanley Carlson-Thies notes, "All federal welfare funds block-granted to the states must be expended in accordance with the charitable choice rules, even in states with constitutional barriers to the expenditure of public funds by sectarian organizations." Stanley W. Carlson-Thies, "Don't Look to Us": The Negative Responses of the Churches to Welfare Reform, 11 Notre DAME J.L. ETHICS \& PUB. POL'Y 667, 672-73 (1997). This provision imposes the federal statute even upon states with contrary state constitutional provisions, and it could pose a special problem if funds are commingled. Section $604 \mathrm{a}(\mathrm{k})$ tries to manage this conflict by noting that "[n]othing in this section shall be construed to preempt any provision of a State constitution or State statute that prohibits or restricts the expenditure of State funds in or by religious organizations." 42 U.S.C. $§ 604 \mathrm{a}(\mathrm{k})$. This provision covers state, but not federal, funds. Currently, at least 27 states prohibit taxpayers' funds from going to any religious organization. See 
not impair their religious expression or character. ${ }^{132}$ At the same time, the provision mandates that the religious freedom of the individual voucher recipient not be diminished by the private provider. ${ }^{133}$ The approved institutions receive reimbursement from the state for each aid recipient served. ${ }^{134}$ Recently, Congress extended charitable choice to Head Start and other federal social service programs. ${ }^{13 .}$

Charitable choice received almost no discussion in Congress nor in public and media debates, which were occupied with other features of the welfare reform. The primary sponsor of charitable choice, Senator John Ashcroft, has stated that the provision "is intended to encourage faith-based service providers to cooperate with public welfare programs by ensuring that they will not have to attenuate or abandon their religious character or style of service."136 Elsewhere, Senator Ashcroft applauded the provision as an effort to shift the setting of social provision from secular, public offices to pervasively re-

Chris Collins, State Officials Will Soon Find Themselves Center in the Legal Debate over Roles of Church, State, GanNETt News SERVICE, Dec. 24, 1997, available in 1997 WL 8843762. However, the Supreme Court's decision in Rosenberger v. Rector of the University of Virginia, 513 U.S. 959 (1994), suggests a willingness to impose the federal standard on a state with such a ban.

132. See 42 U.S.C. $\S 604 a(b)$.

133. See id. $\S 604 \mathrm{a}(\mathrm{d})(1)$.

134. See id. $\$ 604 a(a)(1)$.

135. See Community Opportunities, Accountability, and Training and Educational Services Act of 1998, Pub. L. No. 105-285, Title I, § 201, 112 Stat. 2702, 2729 (codified as amended at 42 U.S.C. $\S \S 9831-46)$. President Clinton apparently believes that the Act excludes pervasively sectarian institutions, while Senator Ashcroft, its chief sponsor, has the opposite view. Compare Statement of the President on Signing the Community Opportunities, Accountability, and Training and Educational Services Act of 1998, 34 WeEKLy CoMP. Pres. Doc. 2148 (Nov. 2, 1998), with 144 CONG. REC. S12,686 (daily ed. Oct. 20, 1998) (statement of Sen. Ashcroft) (disagreeing about whether allowing "pervasively sectarian" organizations to receive Head Start funds would be constitutional).

Ashcroft also seeks legislation to expand the charitable-choice concept to other social services such as housing, juvenile services, and substance abuse programs. See Ashcroft Would Expand 'Charitable Choice' to Help Needy Escape Poverty (Feb. 3, 1999) $<$ http://www.senate.gov/ ashcroft/2-3-99a.htm> (on file with the Duke Law Journal). Support for charitable-choice provisions, permitting the use of federal funds in services provided by religious organizations, can be found among candidates for the presidency in both the Republican and Democratic parties. See Joan Lowy, Gore Stuns Civil Libertarians (May 31, 1999) $<$ http://abcnews.go.com/sections/politics/DailyNews/pn_gorechoice990531.html> (on file with the Duke Law Journal) (describing Vice President Gore's support for charitable choice); 'The Duty of Hope': Bush Outlines \$8 Billion Charitable Plan (July 22, 1999) $<\mathrm{http} / / /$ more.abcnews.go.com/sections/us/DailyNews/bush_xscript990722.html> (on file with the Duke Law Journal) (reprinting Governor Bush's speech, delivered in Texas, that outlines a plan for an $\$ 8$ billion program devolving federal social service programs on religious groups).

136. Carlson-Thies, supra note 131 , at 672 . 
ligious organizations. ${ }^{137}$ Here, the provision proceeds in a spirit suggested by Marvin Olasky, author of The Tragedy of American Compassion, who believes that religious groups do better than government at meeting the needs of the poor, persons with substance abuse problems, and teenagers at risk of pregnancy. ${ }^{138}$ Olasky argues that government-sponsored welfare undermines the spiritual and moral capacities of individuals. ${ }^{139}$ Spiritual renewal indeed can be as or more important than meeting material need. Consequently, the provision of care for the most vulnerable should not be passed through the cold bureaucratic indifference of state-sponsored programs, but instead by means of face-to-face exchanges within a moral community. ${ }^{140}$ Ideally, the provision of care by religious groups adds moral dimensions of expected responsibility and hope, and it facilitates relationships within which people can feel the pressure to change. ${ }^{141}$ John Dilulio puts forth a similar case regarding the provision of services for children, emphasizing that children do not so much need services but instead caring adults in their lives. ${ }^{142}$

According to these views, religious organizations should not merely cooperate with the government to provide child and welfare services, but should serve to replace the government in the welfare

137. See Ashcroft Applauds D.C.'s Use of Private Organizations in Making Welfare Work (Nov. 12, 1998) <http://www.senate.gov/ ashcroft/11-12-98.htm> (on file with the Duke Law Journal).

138. See OLASKY, supra note 27, at 204-09, 214-16, 224-25.

139. See id. at 205-08, 223-26, 231-33.

140. A philosopher far removed from the debate over charitable choice reminds us: "Whatever is serious in religion, whatever is bound up with morality and fate, is contained in those plain experiences of dependence and of affinity to that on which we depend." GEORGE SANTAYANA, LIFE OF REASON 30 (C. Scribner's Sons 1933) (1905).

141. A more skeptical view would question whether the hierarchical, service orientations of the religiously based providers can afford either respect or reciprocal relationships any better than public bureaucracies. See Conversation with Richard Weissbourd, Lecturer, John F. Kennedy School of Government, Harvard University, in Cambridge, Mass. (Mar. 17, 1999). Moreover, it is difficult, but important, to compare ideal versions of the one with the inevitably inadequate practice versions of the other.

142. See Jim Wallis, Criminologist John Dilulio Explains Why a God-Centered and Problem-Focused Approach Is Needed to Save Our Youth, SoJOURNERS MAG. (Sept.-Oct. 1997) $<\mathrm{http}: / /$ www.sojourners.com/soj9709/970910.html> (on file with the Duke Law Journal). In that interview, he also argued:

The only good thing, in my view, that came out of the welfare reform bill was the charitable choice section, which opened up a new possibility of public discourse and dialogue between people who are God-centered and problem-centered and people who may not be God-centered but are also problem-centered. That is where the faith community needs to be in thinking about policy over the next 15 to 20 years.

Id. 
business. Governmental aid fails to move people from dependency, and it may actually harm some recipients by causing self-defeating behavior. Under this view, governmental aid itself leads people to abandon their families, girls and women to become pregnant out of wedlock, and families and communities to abandon those in trouble. ${ }^{143}$ Religious organizations can offer ongoing interactions to connect dependent individuals with others who are independent. Not only do these relationships provide care and attentive connection, but they also offer models of the independence that can break the cycles of dependency. ${ }^{144}$ Evangelical social ministries offer examples for the work contemplated by the Act. ${ }^{145}$

Charitable choice represents a departure from previous governmental arrangements with religious entities in a number of respects that render it vulnerable to constitutional challenge: the inclusion of pervasively sectarian institutions as recipients of public funds; the use of vouchers to connect individuals with religious worship and proselytizing in conjunction with social services; and the real risk that only an identifiable subset of religious groups will participate. Each of these features raises Establishment Clause concerns. The sheer fact that destitute individuals who turn to the state for help are then directed to religious providers could also raise free exercise problems, for the participation of desperate people in religiously styled programs may cross the line into coercion.

a. Pervasively sectarian institutions. Prior to the charitablechoice reform, states and localities often used federal funds to contract with Catholic Charities USA, Methodist Ministries, Jewish Charitable Federations, and other religious organizations in order to provide child welfare services and other human services. ${ }^{146}$ In the

143. Charles Murray is a prominent spokesman for the view that governmental aid produces such perverse incentives. See Charles A. Murray, Safety Nets And the Truly NEEDY: RETHINKING THE SOCIAL WELFARE SYSTEM passim (1982).

144. In her view of the features of social programs that work, Lisbeth Schorr identifies a "spiritual dimension" as one of the elements that fosters change in those seeking drug treatment and other social services. See Lisbeth B. SCHORR, COMMON PURPOSE: STRENGTHENING FAMILIES AND NeIGHBORHOOdS to REBUILD AMERICA 15-17 (1997). She concludes "that it may be easier to establish strong relationships in settings with a spiritual or religious foundation than in secular settings, but faith-based auspices are not the only ones that can cultivate transformative relationships." Id. at 17 . A compelling ethos, generated by a program such as City Year, may supply a comparable sort of faith that assists innovative organizations. See id.

145. See Jim Wallis, The Soul of Politics: Beyond "Religious Right" AND "SECUlar LEFT" 204-09, 229-32 (1995) [hereinafter WALlis, Soul of Politics] (describing efforts within churches to provide spiritual and economic aid to their communities).

146. See Father Brian Hehir, Comments at the Harvard Divinity School Seminar on Demo- 
past, these religiously affiliated organizations provided exclusively secular services. ${ }^{147}$ In contrast, charitable choice permits state contracts not only with religiously affiliated service providers, but also with pervasively sectarian institutions, including churches. ${ }^{148}$ Indeed, the statute explicitly directs that states cannot exclude religious organizations from voucher programs otherwise open to private providers. ${ }^{149} \mathrm{~A}$ church itself, not merely its affiliated social service agency down the street, can receive a state contract to provide services and can be approved to accept vouchers from individuals eligible for public services. The statute also protects the religious character of the faith-based organization that obtains state contracts or receives vouchers. ${ }^{150}$ Thus, these organizations are permitted to maintain the art, scripture, and other symbols associated with their religious order. ${ }^{151}$ They are also exempted from Title VII's ban on religious discrimination in hiring. ${ }^{152}$ The program's inclusion of pervasively religious organizations and the preservation of religious symbols link the public funds and the religious realm more directly than past funding of human services.

By extending public funds to pervasively religious institutions, however, charitable choice may violate the Establishment Clause. Permitting public funds to be used directly to support religious institutions and their messages may have the appearance of advancing religion in violation of the second prong of the Lemon test for analyzing Establishment Clause challenges. Similarly, if the only local provider of services is a single religious organization in which prayer and other religious activities pervade its every feature, this may advance religion and present an excessive entanglement of religion in contra-

\footnotetext{
cratic Revival (Mar. 9, 1998).

147. See id.

148. See 42 U.S.C. $\S 604 a(a)$ (Supp. 1997) (permitting state contracts with "religious organizations").

149. See id. $\$ 604 \mathrm{a}(\mathrm{c})$.

150. See id. $\S 604 a(d)(1)-(2)$. The Act also allows separate accounting procedures for federal funds and thereby shields the rest of the private organization's financial records from public review. See id. § 604a(h)(2).

151. See id. $\$ 604 \mathrm{a}(\mathrm{d})(2)$.

152. See id. $\S \S 2000 \mathrm{e}-1,2000 \mathrm{e}-2$; see also Corporation of the Presiding Bishop v. Amos, 483 U.S. 327 (1987) (approving Title VII's exemption of religious organizations from the ban against religious discrimination). Although not constitutionally required, the exemption prevents potential violations of religious liberty. See Amos, 483 U.S. at 335-36; see also Patty Gerstenblith, Civil Court Resolution of Property Disputes Among Religious Organizations, 39 AM. U. L. REV. 513, $518 \mathrm{n} .22$ (1990) (detailing exemptions of religious organizations from otherwise existing legal requirements).
} 
vention of the Lemon test. If the organization receives public funds not by contract but instead through public vouchers, its status as the only local provider could still raise establishment concerns. ${ }^{153}$ Alternatively, these scenarios could also amount to a governmental endorsement of religion, running afoul of Justice O'Connor's test for Establishment Clause challenges.

Although the pervasively religious character of participating entities is precisely what commends them to supporters of charitable choice, this quality gives rise to an as-applied Establishment Clause challenge as described by the Supreme Court in Bowen. ${ }^{154}$ Such a challenge would require a trial court to assess whether federal grants flow to religiously affiliated institutions that are pervasively sectarian. Perhaps today's Court would not be so concerned with public funds' flowing to pervasively sectarian institutions, but such a conclusion would depart from prior decisions. ${ }^{155}$

In addition, pervasively religious institutions project beliefs that may depart from public values and that enjoy protection from public regulation enforcing public values elsewhere. Particular religious views about the proper roles of women, sexuality, nonmarital parenthood, and interracial intimacy potentially diverge from public commitments to gender equality, privacy, and antidiscrimination on the basis of marital status and race. In the course of receiving help from a pervasively religious agency, an applicant for public assistance or social services may thus confront religious views and policies in direct conflict with public norms. In effect, the use of the religious agency for the delivery of services can supplant public values and erect religious ones in ways that could violate the prohibition against establishing religion or heavily burden individuals' own freedoms of religious belief and practice.

153. It might also unduly burden the free exercise of individuals who feel that they have no other place to turn. See infra notes 67-73 and accompanying text (discussing free exercise challenges).

154. See 487 U.S. 589, 601-02 (1988).

155. The separate opinions in Bowen offer some clues about the views of particular Justices. Justice Kennedy's concurrence, joined by Justice Scalia, emphasized that the provision of funds to a pervasively sectarian institution would not in itself constitute a violation of the Establishment Clause: "The question in an as-applied challenge is not whether the entity is of a religious character, but how it spends its grant." Id. at 624-25 (Kennedy, J., concurring). In contrast, Justice O'Connor's concurring opinion announced that "any use of public funds to promote religious doctrines" would be unconstitutional. Id. at 623 (O'Connor, J., concurring) (emphasis added). 
b. Government aid to worship and proselytizing. The voucher option opens up avenues for federal aid to worship and proselytizing. The statute specifies that "[n]o funds provided directly to institutions or organizations to provide services and administer programs [under charitable choice] shall be expended for sectarian worship, instruction, or proselytization." 156 The important word here is "directly," for it leaves open the possibility that individuals will use vouchers to obtain services that include sectarian worship, instruction, or proselytization. ${ }^{157}$ Indeed, foreclosing these options vitiates the very argument that religiously based social provision holds special promise. Nevertheless, public dollars for such centrally religious activities would appear to advance religion and excessively entangle the state and federal governments with religion, as prohibited by the second and third prongs of the Lemon test. Thus, the individual who holds the voucher would be expected to pray as part of the church program; the provider-agency staff could pray over the recipient; or the recipient and staff could pray together. In each instance, government dollars would be supporting prayer.

As in the earlier analysis of school vouchers, the intercession of private choice could well immunize such expenditures from an Establishment Clause challenge. ${ }^{158}$ The child whose parents use a voucher to select a parochial school exercises a private choice and does not thereby produce a governmental endorsement of religion. Similarly, an individual recipient of a voucher for temporary financial assistance who elects to redeem it at a local church expresses a personal, not a governmental, choice. The individual could then choose a

156. 42 U.S.C. $\$ 604 \mathrm{a}(\mathrm{j})$.

157. A Guide to Charitable Choice offers the following interpretation:

$\mathrm{Q} /$ May a state require that a faith-based organization attenuate or modify its religious convictions or religious style of providing services as a condition of participation?

A/No. The Charitable Choice provision explicitly provides that participating faithbased organizations retain their right to control "the definition, development, practice, and expression" of their religious convictions. However, faith-based organizations may not require beneficiaries to actively participate in religious activities in order to receive services. Further, faith-based providers may not use contract funds to pay for worship services, sectarian instruction, or proselytization, so as to avoid the appearance of governmental promotion of the provider's religious doctrines. No such restriction is necessary in the case of vouchers, where it is the beneficiary who selects the service provider, not the government.

\footnotetext{
A Guide to Charitable Choice (visited Feb. 10, 1999) $<$ http://cpjustice.org/Cguide/ccqanda.html\#general> (on file with the Duke Law Journal).

158. See id. ("Government here is not aiding religion. Rather, it is aiding beneficiaries by means of nongovernmental organizations, some of which may be faith-based.").
} 
program that includes, for example, prayer as part of the contact with the participating nonpublic agency.

Crucial to this defense is individual choice, which requires both sufficient autonomy to choose and sufficient options for the choice to be meaningful. The sheer fact that the arena involves subsistence (as well as day care, substance abuse treatment, and other services crucial to daily survival) renders questionable the assertion that recipients are freely and autonomously choosing. Autonomous choice is in jeopardy when the individual has no money, food, or housing and is offered these necessities on conditions that she might quickly refuse under other circumstances. Consider a single mother who left home with her two preschool children out of fear of domestic violence. Upon arriving at the local church that has the city contract for providing temporary assistance, she may be too afraid to object to the religious character of the services. "Choosing" a religious provider under these circumstances may reflect the kind of duress that calls into question the volition involved. Rather than an individual choosing, we would have a government manipulating and burdening the choice of the individual. Especially if the alternative is farther away, less visible, or less convenient, a voucher recipient may end up with a pervasively religious provider of a particular denomination, despite a desire to receive help elsewhere. Faced with the power of a caseworker to deny eligibility for the voucher in the first place, a destitute and desperate person may be quite reluctant to voice concerns about the location and identity of the service provider.

Another Establishment Clause problem-the delegation of state functions to religious groups-could arise if a state turned all charitable responsibility over to private, religious organizations and left no secular or public option. The statute in fact requires states to provide an alternative to an individual who objects to a particular religious provider, ${ }^{159}$ but the alternative might simply be another religious provider, or even a secular nonprofit entity. The statute does not require preservation of a public governmental option. Elimination of a public, secular option for the distribution of human necessities such as food and shelter would pressure individuals toward a religious option they might not want.

The elimination of a public, secular option may be challenged as a delegation of state functions to religious groups and thus create an-

159. 42 U.S.C. $\S 604 a(e)$. 
other sort of Establishment Clause problem. If a state chooses to turn all of its welfare activities over to one religious organization, this could amount to a delegation of state functions to a religious organization. Such a delegation was rejected by the Supreme Court in Grendel's Den ${ }^{160}$ and Kiryas Joel. ${ }^{161}$ Further, elimination of a public, secular option could expose a state to the kind of political divisiveness along religious lines that the First Amendment was meant to prevent. However, this objection could well fail, given the power retained by the states under the statute to designate which contracting partners and organizations will be permitted to accept vouchers.

c. Jeopardy to the religious free exercise for the destitute and desperate. Voucher programs may directly burden the right of destitute and desperate individuals to exercise freely their own religion or nonreligion, as the case may be. What if the closest provider of food and food stamps requires prayer before any food or food stamps are distributed? Even a staunch atheist who is sufficiently hungry and poor might end up praying. For those who believe in prayer, this could be a wonderful result, but it looks quite different from the perspective of one whose own beliefs take a different shape. It is possible that courts would find individuals seeking temporary public assistance, food stamps, emergency medical and disability assistance, and even substance abuse treatment, vulnerable to coercion, forced to engage in practices they do not support, or forced to put aside spiritual beliefs they otherwise hold.

The statute prohibits discrimination against beneficiaries on the basis of religion. ${ }^{162}$ It also calls upon the states to accommodate an individual who objects to the religious character of the organization from which the individual receives benefits under the Act. ${ }^{163}$ Notably,

160. Larkin v. Grendel's Den, 459 U.S. 116, 122-27 (1982) (holding that the "wall” of separation between church and state is "breached by vesting discretionary governmental powers in religious bodies").

161. Board of Educ. of Kiryas Joel v. Grumet, 512 U.S. 687, 696-702, 706, 709-10 (1994) (plurality) (citing an unconstitutional delegation of state power to churches as one ground for the Court's rejection of the legislative scheme). The Court's general theory in Kiryas Joel emphasized concern that the legislature itself would fail to act neutrally in seeking to accommodate a particular religious community. See id. at 702-05.

162. See 42 U.S.C. $\$ 604 \mathrm{a}$ (g) ("Except as otherwise provided in law, a religious organization shall not discriminate against an individual in regard to rendering assistance funded under any program described in subsection (a)(2) on the basis of religion, a religious belief, or refusal to actively participate in a religious practice.").

163. 42 U.S.C. $§ 604 \mathrm{a}(\mathrm{e})(1)$ provides as follows: 
though, nothing in the Act requires states to notify applicants of such a right to object. The absence of a statutory duty to tell applicants of their option to object to services provided by a religious organization reduces the likelihood of such objections from economically and psychologically vulnerable people. The vulnerability of applicants in need of financial assistance could profoundly affect their ability and willingness to object to the provision of aid through a particular religious organization.

An individual's freedom of religion might be powerfully constrained even by compliance with the statutory requirement that an alternative provider be found within a reasonable time after an applicant's objection to the offer of a religious provider. If no prior arrangements have been made, it could take weeks or even months to locate and to arrange for an alternative provider, and the state could well characterize this as a reasonable time period. For the destitute individual, however, the prospect of an extended wait could lead to giving up on the objection, or suppressing it altogether, at the potential cost of conscientious belief. The secular alternative may impose more difficult transportation or provide fewer hours of service. Litigation may well test the amount of time that would be reasonable for providing an alternative, as well as what it would take to make the right to object sufficiently protective of applicants' rights of free exercise.

d. Participation by an identifiable subset of religious groups. If charitable choice in practice promotes only one religion, or an identifiable subset of religions, or even religious organizations to the exclusion of nonreligious ones, the program could be challenged as an as-applied Establishment Clause violation under a Bowen rationale. ${ }^{164}$ As yet, there is no comprehensive study of how charitable choice works in practice, but there is good evidence that only a limited number of identifiable religious organizations will agree to participate. The National Association of Evangelicals, for example,

If an individual ... [who receives, applies for or requests to apply for assistance] has an objection to the religious character of the organization or institution from which the individual receives, or would receive, assistance funded under any program ... the State in which the individual resides shall provide such individual (if otherwise eligible for such assistance) within a reasonable period of time after the date of such objection with assistance from an alternative provider that is accessible to the individual and the value of which is not less than the value of the assistance which the individual would have received from such organization.

164. See Bowen v. Kendrick, 487 U.S. 589 (1988). 
endorses charitable choice. ${ }^{165}$ Moreover, Father Fred Kammer, the president of Catholic Charities, U.S.A., has suggested that charitable choice can help his organization in its work. ${ }^{166}$ In contrast, Southern Baptist Christian Life President Richard D. Land counsels against participation, because the organization's mission could be corrupted by taking public monies. ${ }^{167}$ Similarly, others warn that government involvement might jeopardize the independence of a religious organization or its religious commitment to serve as advocates for the poor. ${ }^{168}$ The Baptist Joint Committee on Public Affairs believes the

165. See Heeding the Call of the Poor: Let the Church Be the Church (visited Feb. 10, 1999) $<\mathrm{http}: / /$ www.nae.net/resolutions/recent/7.html > (on file with the Duke Law Journal) (resolution adopted by the 55th annual meeting of the National Association of Evangelicals) ("We are encouraged by the 'Charitable Choice' provision of the welfare reform legislation, something we have long promoted.").

166. See National Public Radio, Morning Edition (radio broadcast, Sept. 6, 1996). NPR quoted Father Kammer as saying that "his organization was comfortable with the old restrictions against mixing church and state, and [that] even with the new law, Catholic Charities doesn't plan to change." Id. Father Kammer himself said on the program, "I think it will help even us, though, kind of around the edges. We've had overzealous secularists, I would call them, try to say we could not partner with government or participate in some programs because we were a Catholic charity." Id.

167. See 'Charitable Choice' Entangles Church and State, Say Ethicists (Aug. 29, 1996) $<$ http://www.umr.org/HTfoxhen.htm> (on file with the Duke Law Journal) ("Land ... agreed that with federal funding will come unacceptable government oversight and restrictions."). The commission recently changed its name to the Ethics \& Religious Liberty Commission. Randy Frame quotes the general counsel of the Baptist Joint Committee as opposing charitable choice. See Randy Frame, God in a Box?, CHRISTIANITY TODAY, Apr. 7, 1997, at 46, available in <http://www.christianity.net/ct/7T4/7T4046.html> (on file with Duke Law Journal) ("While the law's supporters claim it is good for religion... it actually violates the Constitution and jeopardizes the healthy neutrality between government and religion.").

168. See Stephen V. Monsma, When SACred and Secular Mix: Religious NONPROFIT ORGANIZATIONS AND PUBLIC MONEY 81-99, 128-29, 154-61 (1997) (reporting that a significant minority of religious social service agencies that have accepted government funds experience conflicts with the government over their religious missions); Carlson-Thies, supra note 131, at 682 (describing the fear among "conservative churches" that "government money comes with strings" that will hinder religious expression); Melissa Rogers, Threat to Religion, SOJOURNERS MAG. (July-Aug. 1998) <http://www.sojourners.com/soj9807/980722b.html> (on file with the Duke Law Journal) (cautioning against charitable choice because "it opens the door to invasive government monitoring, regulation, and accounting of churches and other pervasively sectarian ministries.").

Ironically, Marvin Olasky, whose work is often cited by supporters of charitable choice, urges church groups to resist the temptation of the money and to refuse to partner with the states. Olasky argues that only God can help to reform the vulnerable; thus, church groups should resist the temptation to take any public money that could constrain religious teaching. See Marvin Olasky, Holes in the Soul Matter as Much as Dollars, USA TODAY, Feb. 15, 1996, at 12A; see also Robyn Blumner, And Now, Welfare for Churches (Nov. 1996) $<$ http://www.aclufl.org/welf1196.html> (on file with the Duke Law Journal) (quoting Olasky). Olasky apparently thinks that the welfare reform law did not go far enough because it specifies that its funds must not be used directly to support worship and proselytizing. 
charitable-choice provision is unconstitutional, ${ }^{169}$ as does the American Jewish Committee. ${ }^{170}$ Other religious groups may resist participation because they find the entire welfare reform problematic or even immoral. They can cite their already overburdened shelters and soup kitchens as reasons to reject the premise that religious groups can bail out the government.

A notable discrepancy in the types of religious groups that seek participation could emerge. Then, an as-applied challenge could be mounted to demonstrate an unacceptable pattern of support for only one religion or a select set of religions. ${ }^{171}$ Advancing a limited set of identifiable religious groups with public dollars and public duties would risk governmental establishment of religion and would also exacerbate community divisions over religion.

e. Summary. Charitable choice thus faces potentially formidable constitutional challenges by directing public dollars to pervasively religious institutions, by providing public support for worship and proselytizing, by burdening the free exercise of religion of vulnerable individuals, and by providing support to an identifiable, limited set of religious groups. A state could also be charged with wrongly delegating a governmental function to religious groups if it turned the entire welfare task over to them. Indeed, all the points of potential constitutional vulnerability could grow larger as charitable choice is implemented. Consider the following scenarios:

- The only local provider of services is a single religious organization that requires participation in religious activities.

- The only local provider of services is a single religious organization that does not require participation in religious

169. See Dwight Jessup, Resolution on the Charitable Choice Provision in the New Welfare Act (Oct. 8, 1996) <http://cgibin1.erols.com/bjcpa/timely/charchc.html> (on file with the Duke Law Journal).

170. See Jeremy Leaming, Civil Libertarians Prepare Suit to Bolster Wall Between Church, State (Jan. 8, 1998) <http://www.freedomforum.org/religion/news/980108.asp > (on file with the Duke Law Journal) (describing a potential lawsuit against charitable choice that could include the American Civil Liberties Union the and American Jewish Congress as plaintiffs).

171. Indeed, the Framers of the Constitution, while believing in the social benefits of religion, concluded that "government involvement in sectarian affairs not only unwisely linked the fortunes of religion to the outcome of political squabbles but also necessarily resulted in religious favoritism that gave more religious legitimacy to some religious practices than to others. Free religious practice, American style, could not flourish in such an atmosphere." Kramnick \& Moore, supra note 111, at 47. 
activity, but such activities pervade every contact with the organization.

- To comply with the statutory requirement of an alternative provider within a reasonable time after an applicant's objection, the state contracts with other providers or approves others to receive vouchers, but they are not located in the same town.

- Individuals do not object to the religious character of the services because they are never informed that they may do so, because they are intimidated or threatened that they will not receive services if they do so, or because, like the single homeless mother of two young children fleeing domestic violence, they fear they have no alternative.

In each circumstance, charitable choice could violate both the Establishment Clause and the Free Exercise Clause. If the state directly contracts with the religious organization to provide welfare services, government funds could be seen as advancing and becoming excessively entangled with religion, and the free exercise rights of an individual applicant could be unduly burdened. If social services are redeemed on an individual voucher basis, the Constitution may afford more latitude for the governmental partnership with religious groups because private individual choice interrupts the flow of public money to religious organizations. Yet, the validity of that choice, given the individual's economic and potential psychological privation and actual set of options, could become a genuine question, exposing further constitutional vulnerabilities.

As a sheer matter of policy, my own view is that partnerships between governments and religious organizations may offer better responses to human needs than solely governmental provision, so long as the risks of promoting a limited number of religions and burdening individual beliefs are minimized. ${ }^{172}$ There are many admirable fea-

172. Beyond the charitable-choice provision of the Personal Responsibility and Work Opportunity Reconciliation Act, other federal and state initiatives explore new connections between religious organizations and governments in meeting the needs of poor and dependent populations. Governor George W. Bush has committed Texas to partnerships with religious groups that focus on spiritually based programs in the context of drug treatment and rehabilitation. See INFORMS (Inmate Family Organization Relationship Management System), Texas Governor George Bush: 'You're Changing Lives from the Inside Out', (Mar. 11, 1997) <http://www.cjm.org/Mar97/Mar97.htm\#Texas Governor George Bush:> (on file with the Duke Law Journal); see also Jim Jones, Separation Anxiety: The Line Between Church and State Is Being Erased, Warns a Watchdog Group, FORT WORTH STAR-TelegraM, Jan. 24, 1998, at Life \& Arts 3 (describing one organization's concerns about a Texas pre-release program at a 
tures of charitable choice. It promotes pluralism in the values and settings in which support can be offered, and it strengthens the work of people who are devoted to assisting those in need for reasons larger than a paycheck. Furthermore, religious groups helping those who are impoverished, those who abuse drugs and alcohol, and those who have been unable to put their lives together are more likely to address the individual in need as a whole person, with spiritual as well as material needs, and with the same spark of dignity as the people offering help. For many religiously inspired providers, it is a gift to have the chance to help. ${ }^{173}$ This attitude can grace the encounters between those who give and those who receive help with respect and attentiveness, rather than with bureaucratic indifference. If compatible with the beliefs of the recipient, religious messages and guidance can afford sources of the strength, hope, discipline, and fellowship capable of producing long-term change in the lives of those affected. Thus, charitable choice may hold some promise if it is managed carefully to ensure real choice and to avoid the appearance of governmental endorsement of particular religions or of delegation of public tasks to religious groups. Accordingly, it would be necessary to retain public standards against discrimination on the basis of religion, gender, sexuality, and race; to ensure secular and public options equivalent in value and accessibility; and to make the exercise of such options a genuine possibility, even for very desperate people.

At their best, vouchers for subsistence needs, social services, and schooling promote effective partnerships between public and private actors, between federal and local actors, and between public norms and personal connections. The promise of vouchers, revised to ensure these dimensions of partnership, becomes apparent when contrasted

minimum-security prison in Richmond, "which is the first in the nation to be operated roundthe-clock by a private Christian group"); Mede Nix, Faith, Prison Link Is Explored; Christian Group Seeks Role at Venus Facility, FORT WORTH STAR-Telegram, Aug. 2, 1998, at 1 ("The faith-based prison movement has grown out of Gov. George W. Bush's efforts and legislation designed to get private and religious groups involved in programs that were previously state sponsored, such as welfare-to-work."). Governor Bush has also proposed privatizing the state's welfare system to allow churches to act as local welfare service organizations. Maryland, Mississippi, and Virginia are exploring similar partnerships between religious organizations and the state. Especially in treating substance abuse, there are impressive studies demonstrating greater success rates by groups that are either religiously affiliated or informed by religious belief systems. See Klaus MäKelä et Al., Alcoholics AnONymous as Mutual-Help Movement: A STUdY IN EIGHT SOCIETIES passim (1996).

173. See WAllis, Soul of Politics, supra note 145, at 48-49, 51-56, 82-86, 166-67, 177-81 (discussing how the prophetic spiritual movement can invigorate community-based activism). 
with simpler solutions that underlie contemporary debates over social provision.

\section{THE PROBLEMS WITH SIMPLER SOLUTIONS}

As often touted in the rhetoric of private choice, vouchers create connections between public bodies and private providers. Those connections can be minimal, with the government simply serving as a pass-through agent, or they can be more complex, with the government affecting the content of programs and private entities affecting the government's priorities. The more complex arrangements may trouble people who yearn for simple solutions. Yet, this country has long rejected simple models of social provision and has embraced complex solutions to reflect its diversity and pluralism.

Consider three simple alternatives for organizing social resources to meet the needs of dependents, whether the poor or children:

(1) each "community" is responsible for "its own";

(2) the largest unit of public authority-typically, the national government-is responsible;

(3) no one, or no one outside the immediate family, is responsible. $^{174}$

The first alternative presents definitional problems-what is a "community" and who constitutes "its own"? A community could be defined in geographic terms, in terms of social networks, or in terms of an affiliation with a shared religious, ethnic, or ideological experience or commitment. Society could then organize its social provision by directing that each municipality be responsible for its dependent residents, or that each religious group fulfill the basic needs for adults and children who are affiliated with the religion. There can even be a combination of these geographic and subgroup notions, as the Catholic and Mormon Churches pursue through systems of parishes. ${ }^{175}$ But aside from these crucial definitional problems, this alternative reflects two deeply problematic assumptions.

174. Although I do not directly engage the persistent debate over the causes of povertyalternately attributing it to the character of the poor, to social malfunctioning, or to failures in the economic structure-this array of alternatives reflects that debate.

175. See Mormon Temple First Built in Ohio Since 1838, Dayton Daily News, Aug. 23, 1999, at B2 (explaining the division of Mormons into stakes, akin to dioceses, and wards, akin to parishes); Richard Zneimer, The Rise of America's Spirit of Tolerance, SCHOLASTIC UPDATE, Mar. 1, 1985, at 7, 9 (describing the Catholic requirement that each parish have a school); see also R. LAURENCE MOORE, Religious OUtSIDERS AND THE MAKING OF 
Declaring that each community will take care of its own rests on two assumptions: (1) that all comparable communities, whether geographic, religious, ethnic, or otherwise constituted, will perform the same roles toward dependents; and (2) that no people will be left out of the pattern-no one who will fall outside the "our own" of some community. As an empirical matter, these assumptions are simply not accurate. Abundant historical examples illustrate failed public efforts to require each community to care for its own. The English Poor Laws embraced the principle of local responsibility for the poor. ${ }^{176}$ The 1662 amendment to the Poor Laws not only designed a period of residence as a requirement for receiving assistance, but also directed the return of a newcomer even if he did not apply for assistance. ${ }^{177}$ Several American colonies adopted versions of the English Poor laws. ${ }^{178}$ Plymouth, for example, ruled in 1642 that each town must support its own indigents. ${ }^{179}$ Later, the Plymouth Colony adopted strict residency requirements and placed restrictions on bringing into town anyone liable to become a public charge. ${ }^{180}$ Similar rules were

AMERICANS 48-72 (1986) (examining the origin of ethnically identified Catholic parishes in the United States).

176. See June Axinn \& Herman Levin, Social Welfare: A History of the AMERICAN Response to NeEd 13-14 (4th ed. 1997); MAXWEll H. BloOMFIELd, AMERICAN LAWYERS IN A CHANGING SOCIETY, 1776-1876, at 100 (1976) (discussing the settlement provisions of the Poor Law); E.P. Thompson, THE MAKING OF THE ENGLISH WORKING Class 22223 (1963) (noting that the English poor had a disincentive to migrate to industrial centers for fear of losing their "settlement," or claim to support under the Poor Law); see also Larry Catá Backer, Medieval Poor Law in Twentieth Century America: Looking Back Towards a General Theory of Modern American Poor Relief, 44 CASE W. RES. L. REV. 871 (1995) (finding parallels between the English Poor Law and contemporary welfare policies in the United States).

177. The Settlement Law of 1662 amended the Poor Law to allow authorities to expel anyone likely to become impoverished and to send that person back to the parish of his settlement. See An Acte for the Reliefe of the Poore of this Kingdom, 14 Car. 2, ch. 12, § 6 (1662). American colonies copied this practice. See Benjamin JosePh Klebaner, PUblic PoOr Relief IN AMERICA, 1790-1860, at ch. 4 (1976); Sanford M. Jacoby, The Duration of Indefinite Employment Contracts in the United States and England: An Historical Analysis, 5 CoMP. LAB. L. 85, 88 (1982).

178. See AXINN \& LEVIN, supra note 176, at 15-16.

179. Sotirios A. Barber, Welfare and the Instrumental Constitution, 42 AM. J. JURIS. 159, 163 (1997) (describing welfare schemes in American colonies that mirrored the English Poor Law).

180. See LuCy Komisar, Down And OUt In the USA: A History of Public Welfare 14-15 (rev. ed. 1977). For example, ship captains were charged with any expenses arising from the landing of needy persons in Plymouth; they also had to return such passengers to their place of origin. See Marcus Wilson Jernegan, Laboring and DePendent Classes in COLONIAL AMERICA, 1607-1783, at 192 (Frederick Ungar Publishing 1960) (1931). 
adopted elsewhere in New England and in the Northwestern Territories in 1795 . $^{181}$

Increased geographic mobility created difficulties in implementing the traditional principle that each community was responsible for its own poor. ${ }^{182}$ Each town relied on a notion of "inhabitancy" rather than residence and used a system of "warning out" individuals lacking inhabitancy to lay the basis for removing them from the town if they became public charges. ${ }^{183}$ Hendrik Hartog noted:

The harshness of a warning out system was presumably mitigated by the fact that some town somewhere would have to take in and care for the transient poor.... [B]y definition everyone had an inhabitancy somewhere, no matter how many towns from which an individual had been warned out. The problem was that inhabitancy might be virtually undiscoverable, particularly in a situation where there was no incentive for a town to volunteer itself as a poor person's home. ${ }^{184}$

Even a person who lived for twenty years in a town could be warned out and sent from her home when she became destitute. ${ }^{185}$

Perhaps in response to such problems during the eighteenth century, religious and ethnic groups organized charities to support primarily their own members. ${ }^{186}$ The model of caring for the community's own persisted, but the unit for community was religious, ethnic, or in some cases occupational, rather than secular and governmental. Catholic charities emerged both to fulfill a religious duty and to serve

181. See KomisAR, supra note 180, at 19 (discussing similar laws enacted in the Northwest Territories); Sydney Lens, Poverty: AmericA's Enduring Paradox: A History of the RICHEST NATION's UNWON WAR 38 (1969) (examining comparable laws in New Amsterdam and Rhode Island).

182. See Hendrik Hartog, The Public Law of a County Court, Judicial Government in Eighteenth Century Massachusetts, 20 AM. J. LEGAL HIST. 282, 292-93 (1976).

183. See id.

184. Id.

185. See id.

186. See Sarah Deutsch, No Separate Refuge: Culture, Class, and Gender on AN ANGLO-Hispanic Frontier IN THE AMERICAN SOUTHWEST, 1880-1940, at 26, 154-56 (1987) (describing the development of Hispanic mutual aid societies); ROBERT WUTHNOW, The Restructuring of American Religion: Society and FAith Since World War II 103-06 (1988) (describing the charitable efforts of religious groups); Leon Fink, Labor, Liberty, and the Law: Trade Unionism and the Problem of the American Constitutional Order, in THE CONSTITUTION AND AMERICAN LIFE 244, 249 (David Thelen ed., 1988) (noting the influence of voluntary associations and Christian communalism on the development of trade unions seeking to advance their members' interests). 
as a form of mutual self-help against a difficult and potentially hostile larger world, just as other immigrant groups formed social and fraternal mutual aid societies. ${ }^{187}$ The Italian Missionary Sisters of the Sacred Heart, for example, ran hospitals in New York, Chicago, and Philadelphia especially for Italian immigrants. ${ }^{188}$ In general, Catholic hospitals, agencies, and schools paralleled public hospitals, agencies, and schools. ${ }^{189}$ Private organizations also worked cooperatively with towns and counties on issues of relief. ${ }^{190}$ Yet, these religiously and ethnically based efforts never reached the needs of all members of each group, and they never touched those who lacked sufficiently organized and well-resourced affiliations. ${ }^{191}$ By the end of the nineteenth century, reformers were criticizing the reliance on a system of local charity, because it defeated a principle of public responsibility and prevented the achievement of minimum standards in welfare and education. ${ }^{192}$

As state and federal programs developed in the twentieth century to meet the needs of indigents, localities and states increasingly set minimum residency requirements as a condition for eligibility. ${ }^{193}$ The United States Supreme Court, however, set limitations on such residency requirements in the name of the right to travel. In Shapiro v. Thompson, ${ }^{194}$ the Court rejected a one-year residency requirement

187. Michael B. Katz, In the Shadow of the Poorhouse: A Social History of WELFARE IN AMERICA 63-65 (1986).

188. See id. at 64.

189. See id.

190. See John Drew, The Democratization of Outdoor Relief, in THE AMERICAN Welfare System: Origins, Structure, AND EFFEcts 97, 97-108 (Howard Gensler ed., 1996) (noting that reliance on private organizations during this period was particularly prevalent in the East).

191. See KATZ, supra note 187, at 83-87 (describing the failure of the charitable organization movement); Drew, supra note 190, at 115-20 (recounting criticism that charitable relief efforts were not effectively reaching dependent children); see also MINA CARSON, SetTlement Folk: Social Thought AND THE American SETtLement Movement, 18851930, at 69-121 (1990) (discussing how settlement-house reformers tried to help immigrants unable to deal with industrialization, poverty, and other problems); CREMIN, supra note 35, at 70-84 (describing how institutional churches and settlement houses responded to various social and urban problems); Theda Skocpol, Protecting Soldiers And Mothers: The Political Origins of Social Policy IN THE United STATES 56 (1992) (discussing the role of women's clubs in promoting broad social legislation and of fraternal orders in pressing for government old-age pensions). Skocpol also notes the relative success of women's clubs and the relative failure of the fraternal orders in meeting social needs. See SKOCPOL, supra, at 56.

192. See 2 Edith AbBott, Public Assistance: American Principles and Policies 509-10 (Russell \& Russell 1966) (1940).

193. See Shapiro v. Thompson, 394 U.S. 618, 621-27 (1969).

194. 394 U.S. 618 (1969). 
imposed by local governments. ${ }^{195}$ Similarly, the Court rejected as a violation of equal protection an Arizona statute requiring one year's residence in a county as a condition for receiving nonemergency medical care at county expense. ${ }^{196}$ The Supreme Court most recently affirmed the rationale of these cases in Saenz v. Roe $e^{197}$ in 1999. In a 72 vote, the Court rejected California's effort to limit public assistance for the first year of California residency to the level an individual would have received in the state of his prior residence. ${ }^{198}$ The Court reaffirmed a right to travel under the Equal Protection Clause, including the right to enter and to leave a state, the right to be welcome as a temporary visitor, and the right to be welcome in a new state as a permanent resident..$^{199}$ Moreover, newly arrived citizens are entitled to enjoy the same privileges and immunities as others who share their citizenship. ${ }^{200}$ The Court thus soundly rejected the view, adopted by California, that each state should take care of its own dependents and that individuals should not be able to take advantage of higher levels of support offered in another state, at least during the first year after a move. ${ }^{201}$

The Supreme Court's record has been more mixed when dealing with certain requirements used to limit eligibility for public education. The Court has sometimes approved local residency requirements under the rationale that these residency requirements serve each state's interest in assuring that only state residents take advantage of state educational services. ${ }^{202}$ In addition, localities typically

195. See id. at 631. Interestingly, the abolition of the welfare program itself would have been constitutional in Shapiro. See id. at 633.

196. See Memorial Hosp. v. Maricopa County, 415 U.S. 250 (1974). However, nothing in the Constitution would forbid the government from eliminating nonemergency medical care provided for everyone at county expense.

197. 119 S. Ct. 1518 (1999).

198. See id. at 1524-30.

199. See id. at 1525 .

200. See id. at 1525-26.

201. See id. at 1527-30.

202. See Martinez v. Bynum, 461 U.S. 321 (1983) (upholding a Texas statute authorizing local school districts to deny tuition-free admission to public schools for minors who live apart from parents or guardians and who are present in the district primarily to attend free public schools). States may recognize a guardian rather than a parent as the source of the child's residence under a "best interests" test, but some states are permitted to restrict such devices where a student changes guardianship solely to attend school in the district. See, e.g., Israel S. v. Board of Educ., 601 N.E.2d 1264, 1267 (Ill. App. Ct. 1992).

The courts, however, have struggled over how to handle the residency issue for children who are homeless. The federal district court in the District of Columbia found no claim under 
have the authority to set tax rates used for financing public schools, thus producing dramatic variations in per-pupil expenditures across communities. $^{203}$ This authority provides another way for local communities to express their commitment to take care of their own children, but not the children of others. ${ }^{204}$

In contrast, the Court has struck down citizenship requirements that limit eligibility for certain public programs. In Plyler v. Doe ${ }^{205}$ a plurality of Justices (four out of nine) held that Texas could not deny public education to school-age children who are not citizens or legally admitted aliens. ${ }^{206}$ The plurality opinion found that the state lacked a rational ground for discriminating on the basis of citizenship status, noting that the children were not to blame for their presence in the United States and acknowledging the importance of education in assuring their economic self-sufficiency. ${ }^{207}$ The Supreme Court has since refused to extend Plyler, emphasizing its unique circumstances. ${ }^{208}$ Nonetheless, a federal district court recently revived Plyler when it considered California's Proposition 187, a voter initiative denying

the Stewart B. McKinney Homeless Assistance Act to permit homeless children to enroll in schools connected with their prior residences. See Lampkin v. District of Columbia, No. 920910 (RCL), 1992 WL 151813, at*6-*7 (D.D.C. June 9, 1992). The appellate court reversed, finding that such an enforceable educational right does exist for homeless children. See Lampkin v. District of Columbia, 27 F.3d 605, 612 (D.C. Cir. 1994). On remand, the district court enjoined the District to provide educational services, including transportation. See Lampkin v. District of Columbia, 879 F. Supp. 116, 119 (D.D.C. 1995). Subsequently, the District of Columbia withdrew from the McKinney Act Education Program, which led to a dissolution of the court's injunction. See Lampkin v. District of Columbia, 886 F. Supp. 56, 62 (1995).

203. These variations can be subjected to state limitations established by statute and, increasingly, by courts interpreting state constitutions. See generally Molly S. McUsic, The Law's Role in the Distribution of Education: The Promises and Pitfalls of School Finance Litigation, in Law and School Reform: Six Strategies for Promoting Educational Equity 88 (Jay P. Heubert ed., 1999). Many state courts have held educational finance systems unconstitutional under state constitutional theories. See, e.g., Roosevelt Elementary Sch. Dist. 66 v. Bishop, 877 P.2d 806, 815-16 (Ariz. 1994); DeRolph v. State, 677 N.E.2d 733, 747 (Ohio 1997).

204. Note that in addition to the power of a local community to exclude others by having real estate too expensive for them to buy or rent, the system of "each community cares for its own" generates and sustains inequalities between communities.

205. 457 U.S. 202 (1982).

206. See id. at 221-30.

207. See id. at 220-23.

208. See Kadrmas v. Dickinson Pub. Sch., 487 U.S. 450, 459 (1988) (upholding a North Dakota program permitting local school boards to assess a user fee for transporting students to and from public schools and explicitly noting that the Court has not extended the holding of Plyler beyond the circumstances that provoked its unique confluence of theories and rationales). 
public education to undocumented immigrant children. ${ }^{209}$ The court, relying in part on Plyler, rejected substantial portions of the proposition as unconstitutional and then approved an agreement between the state of California and civil rights groups to drop remaining portions of the suit. ${ }^{210}$

Thus, despite the attraction of reserving to local towns and states the primary responsibility for taking care of their own, localities and states have not been free to exclude individuals on the basis of residency or citizenship. The model of each community caring for its own has come into conflict with contemporary norms, as well as judicial interpretations of the constitutional rights to equal protection of the laws, due process, and the freedom to travel. Even though majorities of those voting for state initiatives and legislation often revive the community model, hard-won and now-settled interpretations of the Constitution sharply limit the ability of states and localities to exclude individuals seeking aid. ${ }^{211}$

The second simple alternative would place responsibility for social provision and education in the public, rather than the private, sector, pinning the ultimate duty on the federal government. This alternative does not require the federal government itself to create and to operate social welfare agencies, schools, food pantries, and the like. It only demands that the federal government ensure the performance of social provision and education, whether through directives, contracts, or cooperative relationships with state and local governments, religious groups, and other private entities. ${ }^{212}$ A paradig-

209. See League of United Latin Am. Citizens v. Wilson, 908 F. Supp. 755, 785 (C.D. Cal. 1995). Proposition 187 reflects the goal of ensuring that undocumented aliens in the United States do not receive benefits or public services in the state of California. Sections 7 and 8 specifically exclude undocumented aliens from public elementary, secondary, and postsecondary schools in the State. See id. at 787-91.

210. See id. at 774, 785; see also Tom Harrigan, Judge Oks Agreement Ending Attempts to Revive Prop. 187, SAn Diego Union-Tribune, Sept. 14, 1999, at A3. The federal judge in League of United Latin American Citizens further ruled that Proposition 187 could not stand in the face of the Personal Responsibility and Work Opportunity Reconciliation Act of 1996, which demonstrated the federal occupation of the domain of immigrant access to public benefits. See League of United Latin Am. Citizens, 997 F. Supp. at 1253-55; see also Patrick J. McDonnell, Judge's Final Order Kills Key Points of Prop. 187, L.A. TIMES, Mar. 19, 1998, at A3; Patrick J. McDonnell, Prop. 187 Found Unconstitutional by Federal Judge, L.A. TIMES, Nov. 15, 1997, at A1. The Governor dropped plans to appeal as part of a mediated settlement of the remainder of the suit. Groups that helped to draft Proposition 187 may themselves seek further appellate review. See Harrigan, supra, at A3.

211. See supra notes 193-201 and accompanying text.

212. See, e.g., AXINN \& LEVIN, supra note 176, at 174-202 (examining a range of partner- 
matic example is Social Security, the federally administered and federal-based entitlement program for the elderly. ${ }^{213}$ In the context of the poor, however, the recent elimination of an enforceable federal entitlement signals a rejection of federal responsibility for social provision of the poor. ${ }^{214}$

This country, unlike others, has also rejected federal responsibility for children's education. ${ }^{215}$ It is true that the federal government subsidizes public education with specially targeted monies to assist programs for children in poverty and children with special educational needs. ${ }^{216}$ The Supreme Court has also commanded equal availability of public education within a state that has chosen to provide it. ${ }^{217}$ Despite this mandate, the responsibility for education has fallen mainly on the states and localities. All of the state constitutions guarantee public education for children, and school-financed litigation over the past several decades has produced court orders in some states specifying a right to an effective education. ${ }^{218}$ Given the reliance of such lawsuits on particular state constitutional commitments, no uniformity has emerged across the nation. Consequently, massive disparities continue to exist in expenditure, quality, and opportunity both within and across the states. The democratic and constitutional processes in the country have treated federal responsibility for social provision and education as unworkable and undesirable. Indeed, the Supreme Court has construed the Constitution even to forbid state

ships with states and private agencies, direct federal grants, and federally mandated benefits adopted during the New Deal).

213. See 42 U.S.C. §§ 301-1397 (1994) .

214. See Personal Responsibility and Work Opportunity Reconciliation Act of 1996, 42 U.S.C. § 1305 (Supp. III 1997).

215. See San Antonio Ind. Sch. Dist. v. Rodriguez, 411 U.S. 1, 35, $54-55$ (1973) (rejecting the theory that education is a fundamental federal right and upholding a scheme for state-wide school financing that resulted in unequal per-pupil expenditures between districts). The Court has also ruled that parents have the right to choose private schools for their children. See Pierce v. Society of Sisters, 268 U.S. 510, 534-35 (1925) (concluding that a state may not require attendance in public schools in order to fulfill compulsory school requirements).

216. See Elementary and Secondary Education Act of 1965, Pub. L. No. 89-10, §§ 201-12, 79 Stat. 27, 27-32 (codified as amended in scattered sections of 20 U.S.C.) (providing financial support and incentives for specific state educational programs); Individuals with Disabilities Education Act, 20 U.S.C. $§ 1412(a)(1)$ (Supp. III 1997) (establishing standards for free appropriate education for children with disabilities).

217. See Brown v. Board of Educ., 347 U.S. 483, 493 (1954) (declaring that educational opportunity, "where the state has undertaken to provide it, is a right which must be made available to all on equal terms").

218. See McUsic, supra note 203, at 102-15, 134-37. 
and local governments to hold a monopoly on education. Public compulsory schooling laws must permit parents to opt out of public schools for religious or other private options. ${ }^{219}$

The third alternative-responsibility resting on no one, or at least no one outside the immediate family-leaves social provision and education to the voluntary actions of individuals. With regard to care for the poor, the homeless, or otherwise dependent individuals, this nation seems to be drifting toward this model. With regard to schooling, this model seems moot, since each state has adopted compulsory school laws and state constitutions include a provision assuring children some kind of access to basic education. ${ }^{220}$ Therefore, at least by state law, the polity has designated public responsibility for provision of education, at least through high school. ${ }^{221}$ The remaining domain of private family responsibility in our system includes parental prerogatives to select private schools, subject to the family's ability to pay or to obtain scholarships, and parental duties to supervise children's educational experiences, including homework.

Nonetheless, the potential exists for the third alternative to become a more salient feature of American education. As schooling moves into a more competitive model, either within the public system or across public and private options, parents are given greater responsibility for selecting schools for their children. As a result, children will become increasingly dependent on their parents' or guardians' exercising informed choices. The quality control for education then will be shifted at least partially from the public sector to individual parents. When parents or guardians lack the ability, motivation, or knowledge to fulfill this function, the third alternative becomes more germane. ${ }^{222}$ Even if school choice is coupled with communal or

219. See Pierce, 268 U.S. at 534-35. Under special circumstances, the Court also permitted Amish parents to evade enforcement of compulsory schooling after their children completed eighth grade. See Wisconsin v. Yoder, 406 U.S. 205 (1972).

220. See CREMIN, supra note 35, at 297 (noting that all states then in the Union had adopted compulsory education laws by 1918). On state constitutional provisions governing education, see McUsic, supra note 203, at 103.

221. See Pierce, 268 U.S. at 534. This case helped to inspire a movement for home-schooling by parents. See Jon S. Lerner, Comment, Protecting Home Schooling Through the Case Undue Burden Standard, 62 U. CHI. L. REV. 363, 371-73 (1995).

222. See The Limits of Choice, supra note 19, at 2002-03 (claiming that school choice reforms "risk creating pockets of failure-public schools in economically depressed areas ... that serve a body of uninvolved parents and guardians," and asserting that "[e]ven if a competitive education market ultimately weeds out deficient schools, until those schools go out of business, students will be deprived of an adequate education"); see also Joseph G. Weeres \& Bruce Coo- 
federal obligations, such "choice" may take place in a world of insufficient numbers of quality schools, inadequate information about the stakes and alternatives, and large numbers of people unable to use the choice system effectively. This state of affairs means choice for some and not for others, and whether a child's educational needs are met will depend on her parents' ability to choose.

Advocates of school choice claim that competition will favor those schools that deliver better results and that over time the bad schools will close and disappear. ${ }^{223}$ It remains to be seen, however, if the system will work out a timely, practical mechanism for identifying and shutting down "failing" schools before their students have lost meaningful chances to receive education elsewhere. ${ }^{224}$ Vouchers, in the meantime, may make liberty the only value-and in practice, liberty only for some. Combining vouchers with state or federal standards, however, could propel equality of opportunity as well as liberty, quality as well as choice, and central responsibility as a paradoxical correlate of local control.

As this brief discussion indicates, our country has properly resisted simple models for social provision and education. ${ }^{225}$ We have embraced more complex solutions that combine notions of community responsibility, local government and private activities, and national standards. We should continue to do so. Voucher proposals for schooling and for charitable choice have the potential for fostering combinations of religious and secular providers in a general scheme of social provision. Public dollars can be accompanied by basic public standards to protect against the abandonment of each person and family, left always to provide for themselves. This political moment

per, Public Choice Perspectives on Urban Schools, in THE Politics of Public EduCATION IN THE UNITED STATES 57, 67 (James V. Cibulka et al. eds., 1992) (arguing that market solutions require: (1) equally legitimate differences in preferences; (2) individuals who are knowledgeable about the quality of services and able to evaluate and to compare them; (3) individuals who can freely move from one supplier to the next and learn from experience; and (4) many competing providers).

223. See Greg D. Andres, Private School Voucher Remedies in Education Cases, 62 U. CHI. L. REV. 795, 814 (1995). For a thorough treatment of how vouchers will affect failing schools, see The Limits of Choice, supra note 19.

224. See Note, The Hazards of Making Public Schooling a Private Business, 112 HARV. L. REV. 669, 698-712 (1999) (describing the problems of resorting to a market system of education and arguing for standards-based reform rather than privatization).

225. Other systems have their own complications. Canada, for example, has a system that pays for Catholic as well as public schools; currently, parents of other religions have argued that public funds should also support their religious schools. See P. Jameson McCloskey, Ontario Case Tests Religious-School Financing, N.Y. TIMES, Oct. 30, 1996, at B4. 
holds rich promise for reinvigorated public conversation about meeting human needs as federal governmental commitments decline. Religious and other private groups have always helped to meet the basic human need for food and shelter of people at the economic margins; they have also developed some of the best schools for children. ${ }^{226}$ As public welfare ends and a politics of selfishness rises, the steadfast commitment of many religious groups to the poor and to children is notable and commendable. But religious groups cannot fill in the holes of a gouged public safety net; nor can they develop the capacity to educate all American children. Religious provision can never substitute for secular alternatives or provide public norms of equality and fairness. ${ }^{227}$

How should we promote productive connections between these religious providers and governments? Most helpful now would be enlargement of the commitments within communities and within the nation to meet the needs of those who are impoverished and those who are stuck in poor quality schools. This calls for work internal to religious communities and localities, but also for a public, civic space to connect impulses of compassion with democratic and constitutional norms. To this end, we need to conceive of partnerships and coordination efforts to enhance the actual delivery of services and schooling, to enlarge respect both for human individuality and for vital communities of faith and tradition, and to strengthen intellectual and moral resources to deal with the potentially destructive features of global markets.

\section{CONCLUSION}

Assigning exclusive responsibility for schooling and social services to governments violates constitutional protections for free exercise of religion, as well as good sense about the value of pluralism and the quality of programs infused with religious commitments. ${ }^{228}$ Yet,

226. For electronic resources connecting religious groups and laypeople interested in social supports and community renewal, see Religion and Civic Culture Online, (visited Sept. 15, 1999 ) <http://www.usc.edu/dept/LAS/religion_online> (on file with the Duke Law Journal).

227. Other features of public schooling, crucial to enabling and fulfilling public norms of equality and fairness, include equitable school finance, civic education, and curricular programs that reflect and instill these values.

228. The constitutional objection to exclusive governmental provision of schooling, articulated in Pierce v. Society of Sisters, 268 U.S. 510 (1925), was bolstered by recognition of parental prerogatives to guide their children's development, as well as the freedom of the school providers to pursue their business and profession. In this lawsuit arising from intergroup conflicts, 
abandoning to either private communal groups or individual families all public commitment to schooling and social provision is also unwise and contrary to commitments to equality, fairness, and individual dignity. A more complicated set of partnerships between governments and private groups, mixing public norms and individual action, may be less elegant, but it is more likely to preserve and to promote the crucial purposes of private choice, religious and ethnic freedom, social cohesion, and equal opportunity and respect across religious and racial groups for both men and women. Pluralism, maintained consistently with and through public norms, can promote individual freedom, equality, and mutual respect among different groups. This nation has embraced pluralism nurtured by and conditioned upon guarantees of individual freedom and equality. ${ }^{229}$ This pluralism must make room for entities, such as schools, social services, and providers of basic human needs that are religiously affiliated, but also for similar entities that are not religiously affiliated. This kind of pluralism should guard against the governmental establishment of religion and preserve free exercise of religion for individuals; it should also afford resources for critiquing and monitoring state alliances with global market forces. A robust independent sector and vibrant religious communities are thus worthwhile not only for their own purposes and for the immediate good they do for others, but also for nurturing normative centers in which people can articulate values potentially at odds with this global moment. Fostering public and pri-

the Court rejected state legislation that would have made attendance at a public school compulsory. See Martha Minow, We the Family: Constitutional Rights and American Families, in The Constitution AND AMERICAN Life 299, 304-05 (David Thelen ed., 1988). No comparable decision exists in the realm of welfare or social provision. However, in DeShaney v. Winnebago County Department of Social Services, 489 U.S. 189 (1989), a Supreme Court majority implicitly rejected the dissenters' view that the creation of a state department to guard against child abuse created a state monopoly in that area, see id. at 197-98, perhaps acknowledging that governments have never actually tried to do so.

\section{See JAmes, A Pluralistic UnIVERSE, supra note 6, at 321-22:}

Things are 'with' one another in many ways, but nothing includes everything, or dominates over everything. The word 'and' trails along after every sentence. Something always escapes. . The pluralistic world is thus more like a federal republic than like an empire or a kingdom. However much may be collected, however much may report itself as present at any effective centre of consciousness or action, something else is self-governed and absent and unreduced to unity.

See also THIEMANN, supra note 55, at 146-51 (focusing on the Free Exercise Clause as one foundation for a pluralistic society and arguing that, in light of this country's heritage as a "melting pot," the Framers of the Constitution anticipated the potential for factionalism and developed a government around the core values of liberty, equality, and tolerance to deal with these pressures). 
vate cooperation, while pursuing some limits on the partnerships with religious entities, can promote mutual aid and preserve the distinct contributions each kind of entity makes to the needs of the poor, of children, and of the larger society.

Michael Ignatieff's elegant book The Needs of Strangers captures two crucial yet potentially conflicting insights for societies that mean to be democratic, pluralist, and decent. Ignatieff first notes that "[w]e need justice, we need liberty, and we need as much solidarity as can be reconciled with justice and liberty." endorse and celebrate liberty and justice as primary to human society. ${ }^{231}$ Rights for individuals afford chances to break away from inherited social stations, as well as opportunities to challenge exclusions and degradations based on religion, race, or other traits. ${ }^{232}$ Liberty and equality should guide political structure. ${ }^{233}$ This includes religious liberty and freedom from discrimination on the basis of religious affiliation-or non-affiliation. ${ }^{234}$ Alternatives that subordinate such liberty and equality to solidarity, or any other purpose, are worse and undesirable. ${ }^{235}$ Social solidarity too often comes at the price of foreshortened liberty, equality, and justice for the variety of distinct human beings. ${ }^{236}$ Even if it were possible to arrange a world in which "each community cared for its own," the enforcement required would constrain individuals intolerably. ${ }^{237}$ Therefore, only the forms of social solidarity compatible with these watchwords should be promoted in constitutional democracies. ${ }^{238}$

Yet, here is Ignatieff's important, additional insight: "It is because money cannot buy the human gestures which confer respect, nor rights guarantee them as entitlements, that any decent society requires a public discourse about the needs of the human person." ${ }^{239}$

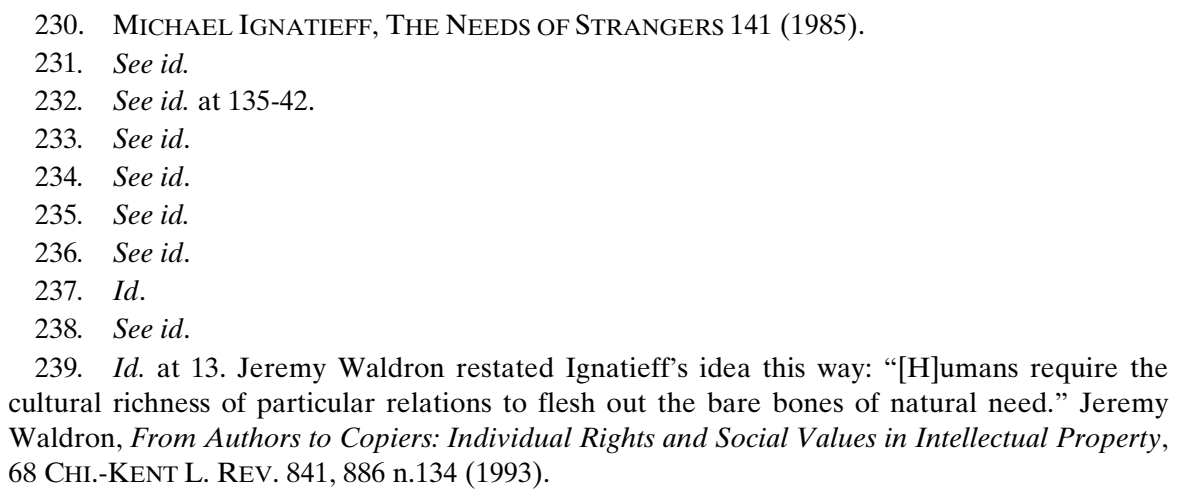

239. Id. at 13. Jeremy Waldron restated Ignatieff's idea this way: "[H]umans require the cultural richness of particular relations to flesh out the bare bones of natural need." Jeremy Waldron, From Authors to Copiers: Individual Rights and Social Values in Intellectual Property, 68 CHI.-KENT L. REV. 841, 886 n.134 (1993). 
The welfare systems that many democracies have produced are demeaning and inadequate; too many public schools across the nation deserve the same adjectives. Neither money nor entitlements administered by a bureaucratic state can guarantee the basic human needs for respect, care, connection, and genuine opportunity to flourish. Placing primary responsibility for those in need with the national government is highly unlikely to achieve these goals. Nor, of course, would abandoning all public responsibility for those in need outside the individual or immediate family. It is important to resist the faulty assumption that local, private (including religious) initiatives can or always will afford the human gestures that confer respect and also the basic social provision that is necessary for the destitute to survive. Choice might help improve schools and services, but not if exchanged for the norm of equal regard.

The movements for school choice and for charitable choice reflect the admirable belief that we can and therefore must make better schools available to more children and provide more meaningful public assistance with strong community ties. These movements also embody fair criticisms of the public bureaucracies that have made too many schools and too many social service programs dehumanizing and incompetent. However, general rules should remain to guide local schools and human services. Ultimately, it is a collective responsibility to ensure that no one is abandoned to starvation, privation, or to a dead-end, dismal school.

Even with the best motivations, private groups, including religious groups, can demonstrate biases against individuals or members of other groups. They can perpetuate longstanding lines of exclusion or degradation on the basis of race, gender, or religion. They can leave untouched or exacerbate legacies of intergroup conflict and stigmatized group memberships. They can fail to build sufficient capacity to reach all with comparable needs. More basically, beyond including private religious groups as options in the delivery of education and human services, the shift to choice may come to mean shedding public responsibility for social provision. This would be a costly change, potentially devastating to the very fabric of society. Even individually attractive choices cannot add up to a shared context for pursuing the common good. Without that shared context, there is no setting for debating what everyone deserves, no method for ensuring that choices are real for everyone, and no coordination of the infor- 
mation and accountability standards that no private individuals or groups can ensure.

The push for using public dollars to pay for private and religious schools poses a challenge to the shared context that connects private and public lives. Although the commitment to pluralism, religious freedom, and parental rights has long promised parents the authority to opt out of the common public schools, ${ }^{240}$ that option has remained until now just that: an option, leaving in place public schooling as the norm. Only the public schools have received direct public support, although nonprofit private schools remain eligible for the more modest assistance of tax exemption and incidental aid for transportation and books. ${ }^{241}$ The current school-choice movement calls for directing the funds set aside by society to educate youth outside of this public system. Channeled by parents to a variety of schools of their own choice, the funds may not violate the existing constitutional scruples against direct public aid to religious schools. Nevertheless, this very channeling dismantles the idea of a common school, open to all, capable of integrating students from a variety of backgrounds, and committed to inculcating a shared American tradition. However elusive that ideal has been - given racial and class segregation and implicit preferences for particular versions of the American tradition-the ideal itself has both symbolized and fertilized the shared context that binds diverse Americans together. Without that ideal, the prospects for a common language and for a public domain in which citizens grapple to frame the common good become far less certain.

The injection of private religious options into the delivery of welfare services is perhaps less worrisome because food and shelter, job training, and drug treatment do not hold the place of civic and cultural meaning that schooling does. Here the risk lies more in unwitting, or witting, exclusions and coercions violating the freedoms that have imbued the nation's ideals.

Recognizing the power of arguments for school choice and charitable choice, I do not think that constitutional law should prevent at least small-scale initiatives in these directions. Indeed there is a need for experimentation in these areas, in which so many prior efforts

240. See Wisconsin v. Yoder, 406 U.S. 205, 213-15 (1972); Pierce v. Society of Sisters, 268 U.S. 510, 534-35 (1925). However, even the parental right to opt out of public education has limits, "if it appears that parental decisions will jeopardize the health or safety of the child, or have a potential for significant social burdens." Yoder, 406 U.S. at 234.

241. See supra notes $72-81$ and accompanying text. 
have failed so many people in need. However, the details will profoundly influence the prospects for commonality, respect across different groups, and inclusion. Four kinds of federal and state regulations should frame any options that become eligible for public funds in the contexts of schooling and welfare reform.

First, no private school or program should be eligible for payment through public dollars or vouchers if it excludes individuals on the basis of race, ethnicity, or nationality. ${ }^{242}$ Second, any religious school receiving public funds or vouchers must engage in educational programming to address the legacies of intergroup hatred and conflict and to promote tolerance and respect across religious, racial, and ethnic groups. Such programs should include not only in-class curricula but also extracurricular music, sports, and other activities directly connecting students with peers from other schools of different or no religious affiliation. Here it would be important that students from different schools join in the same teams, orchestras, and theater groups-not merely participating in opposing or competing groupsso that students actually have the chance to work together on common projects and to get to know one another in that context. ${ }^{243}$ Third, neither charitable-choice nor school voucher programs should be allowed to eliminate a genuinely accessible and attractive secular option for people who do not want to deal with a religious provider of services or schooling. Fourth, all participating programs and schools must supply comparable information to watchdog and public groups to permit comparisons of their operations and outcomes. These requirements offer a minimal guard against segregated, self-confirming enclaves and the erosion of the shared public space necessary to a complex, pluralistic society.

Though some private religious providers may find these conditions too intrusive or onerous, they can always opt out of participation. Moreover, none of these conditions dictates how a private entity should run its services; they simply identify basic criteria for eligibil-

242. Given the ongoing research about the value of same-sex education, same-sex job training programs, same-sex drug and alcohol treatment programs, and services tailored for individuals with particular disabilities, I would not be ready to ban exclusion on the basis of sex and disability by particular programs, so long as the system as a whole ensures comparable treatment opportunities for all-but this requires the maintenance of some system-level analysis and evaluation, rather than simple reliance on market results.

243. See generally MARTha Minow, Not Only fOR Myself: IdENTITy, Politics, AND THE LAW 128-31 (1997) (reviewing research about such integrative programs). 
ity. Would such requirements be politically feasible ${ }^{244}$ If adopted, would they be administrable? These are fair questions that I hope will be aired and addressed if religious groups and others participate in a broad public debate about how to arrange for social provision in a pluralist society committed to tolerance, liberty, and equality. That debate could, and should, be informed by the failure of simple solutions and the efficacy of complex ones.

Initiatives that do seem to work involve complex mixtures of resources: public and private, federal and local, professional and lay, legal and cultural. Consider, for example, Head Start. A federal program with roots in the religious activism of communities of Southern women, Head Start has always combined federal and local norms, as well as federal and local representatives. ${ }^{245}$ Mandated roles for parental involvement make Head Start an unusual but intriguing example of the way in which national law can structure gestures of care and encourage respect for those who are otherwise constructed as the needy. Public and private agencies collaborate in training, delivery of services, and evaluation. There is nothing simple about it. Another example is the Indianapolis Front Porch Alliance. ${ }^{246}$ The city, led by a Republican mayor, initiated work with community organizations and

244. Many of the religious groups most likely to participate in charitable choice and in the running of schools will resist regulations that seem to bring the government inside their worlds. Indeed the stifling, bureaucratic quality of regulation is precisely what seems to argue for the use of alternatives to meet human needs. However, if public dollars are at stake, public values should frame the outer bounds of their use. Those organizations that refuse principles of nondiscrimination, participation in districtwide activities, and the sharing of information can certainly choose not to accept the public dollars. It is worth noting that public solicitude for religious activities can be expressed in different degrees. Direct contractual relationships create more mutual involvement than do vouchers. Tax-exempt status, on the other hand, provides support less directly than both contracts and vouchers, but even tax-exempt status can, and should, be denied where the religious entity violates national norms. See Bob Jones Univ. v. United States, 461 U.S. 574, 591-92 (1983) (upholding an Internal Revenue Service decision to deny tax-exempt status to private schools engaging in racial discrimination).

245. See Richard C. Boldt, A Study in Regulatory Method, Local Political Cultures, and Jurisprudential Voice: The Application of Federal Confidentiality Law to Project Head Start, 93 MICH. L. REV. 2325, 2343-45 (1995); Lucie White, On the Guarding of Borders, 33 HARV. C.R.-C.L. L. Rev. 183, 189 (1998); Lucie White, "Why Do You Treat Us So Badly?": On Loss, Remembrance, and Responsibility, 26 CUMB. L. REV. 809, 813-14 (1996). See generally Edward Zigler \& Susan Muenchow, Head Start: The Inside Story of America's MOST SUCCESSFUL EDUCATIONAL EXPERIMENT (1992).

246. See Jo Loconte, The Bully and the Pulpit: A New Model for Church-State Partnerships, J. Am. Citizenship, Nov./Dec. 1998, at 28; Stephen Goldsmith, Sources of Strength in Community, Indianapolis STAR, May 27, 1998, at A11; David Holmstrom, Front Porch Alliance Fosters Church-City Cooperation, CHRISTIAN SCI. MONITOR, May 13, 1998, at 12. 
religious congregations to create a kind of "civic switchboard connecting private and appropriate public resources with grassroots leaders" to meet community needs while helping to shape values, to instill hope, and to honor virtue. ${ }^{247}$ The public role involves monetary support and symbolic endorsement, as well as matchmaking and information-sharing. ${ }^{248}$ The community organizations and religious groups now meet the needs of far more individuals-not merely those whom they see and identify on their own-because the government has engaged, rather than displaced, these local and rooted sources of authority and commitment. ${ }^{249}$

Perhaps there is some comfort in messy realities that defy simple models. ${ }^{250}$ Ours is not a nation that has ever abandoned, or foreseeably ever would abandon, the complex mix of authority, responsibility, and community found in the parallel realms of the public and private, the religious and secular, the local and regional, and the state and federal. In responding to the poor and in educating children, ours is a complex and untidy system. "America, it would seem, is miraculously both singular and plural, organized and scattered, united and diffused." 251 Can this complexity be preserved alongside commitments to justice, liberty, and as much solidarity as is compatible with each? Can our traditional pluralism be strengthened by collective discussions of human need? The public square should be filled with boisterous, conflicting views about how to address these questions. It should also sustain and deepen the commitment to enlarge the "we," the sense of who is in this life together, of who is within the ambit of concern and the community of participants. Ensuring this is the challenge of the current moment.

247. See Goldsmith, supra note 246, at A11.

248. See id.

249. See id.

250. Cf. Mary Ann Glendon, Knowing the Universal Declaration of Human Rights, 73 Notre DAme L. ReV. 1153, 1176 (1998) (admiring a sculpture by Arnaldo Pomodoro, located by the United Nations building, depicting a cracked globe with another, cracked sphere emerging from inside as a metaphor for the dynamism, potency, and emergent probabilities of politics guided by principles to which people of vastly different backgrounds can appeal).

251. Michael Kammen, People of Paradox: AN INQuiry CONCERning THE ORIGins of American Civilization 57 (1973) (quoting Henry S. Kariel, The Decline of AMERICAN PLURALISM (1961) (page number omitted in original)). 